\title{
A Review on SARS-CoV-2-Induced Neuroinflammation, Neurodevelopmental Complications, and Recent Updates on the Vaccine Development
}

\author{
Medha Karnik $^{1}$ - Narasimha M. Beeraka ${ }^{1,2}$. Chinnappa A. Uthaiah ${ }^{1}$. Suma M. Nataraj ${ }^{1}$ Anjali Devi S. Bettadapura ${ }^{1}$. \\ Gjumrakch Aliev ${ }^{2,3,4,5}$. SubbaRao V. Madhunapantula ${ }^{1,6} \mathbb{D}$
}

Received: 9 February 2021 / Accepted: 19 April 2021 / Published online: 5 June 2021

(c) The Author(s), under exclusive licence to Springer Science+Business Media, LLC, part of Springer Nature 2021

\begin{abstract}
Coronavirus disease 2019 (COVID-19) is a devastating viral infection caused by severe acute respiratory syndrome coronavirus 2 (SARS-CoV-2). The incidence and mortality of COVID-19 patients have been increasing at an alarming rate. The mortality is much higher in older individuals, especially the ones suffering from respiratory distress, cardiac abnormalities, renal diseases, diabetes, and hypertension. Existing evidence demonstrated that SARS-CoV-2 makes its entry into human cells through angiotensin-converting enzyme 2 (ACE-2) followed by the uptake of virions through cathepsin L or transmembrane protease serine 2 (TMPRSS2). SARS-CoV-2-mediated abnormalities in particular cardiovascular and neurological ones and the damaged coagulation systems require extensive research to develop better therapeutic modalities. As SARS-CoV-2 uses its S-protein to enter into the host cells of several organs, the S-protein of the virus is considered as the ideal target to develop a potential vaccine. In this review, we have attempted to highlight the landmark discoveries that lead to the development of various vaccines that are currently under different stages of clinical progression. Besides, a brief account of various drug candidates that are being tested to mitigate the burden of COVID-19 was also covered. Further, in a dedicated section, the impact of SARS-CoV-2 infection on neuronal inflammation and neuronal disorders was discussed. In summary, it is expected that the content covered in this article help to understand the pathophysiology of COVID-19 and the impact on neuronal complications induced by SARS-CoV-2 infection while providing an update on the vaccine development.
\end{abstract}

Keywords SARS-CoV-2 $\cdot$ Neurological damage $\cdot$ Coagulation $\cdot$ ACE-2 $\cdot$ S-protein $\cdot$ Vaccine

\begin{tabular}{|c|c|c|c|}
\hline Abbreviation & & RBD & Receptor-binding domain \\
\hline COVID-19 & Coronavirus disease & RBM & Receptor-binding motif \\
\hline SARS-CoV & Severe acute respiratory syndrome & RNA & Ribonucleic acid \\
\hline & coronavirus & ORF & Open reading frame \\
\hline SARS-CoV-2 & Severe acute respiratory syndrome corona- & Nsp & Non-structural proteins \\
\hline & virus 2 & S-protein & Spike protein \\
\hline $\mathrm{CoV}$ & Coronavirus & N-protein & Nucleocapsid protein \\
\hline MERS & Middle East respiratory syndrome & M-protein & Membrane protein \\
\hline $\mathrm{hCoV}$ & Human coronavirus & E-protein & Envelope protein \\
\hline ACEIs & Angiotensin-converting enzyme inhibitors & DC-SIGN & Dendritic cell-specific intercellular adhe- \\
\hline ARBs & Angiotensin II receptor blockers & & sion molecule-3-grabbing non-integrin \\
\hline NTD & $\mathrm{N}$-terminal domain & L-SIGN & Liver/lymph node-specific intercel- \\
\hline & & & lular adhesion molecules-3-grabbing \\
\hline Medha Karnik and & Narasimha M. Beeraka contributed equally to & DPP4 & Dipeptidyl peptidase 4 \\
\hline & & HCQ & Hydroxychloroquine \\
\hline$\triangle$ SubbaRao V. I & Madhunapantula & IFNs & Interferons \\
\hline mvsstsubbarao & @jssuni.edu.in & RAS & Renin-angiotensin system \\
\hline Extended author in & aformation available on the last page of $t$ & $\mathrm{ACE}$ & Angiotensin-converting enzyme \\
\hline
\end{tabular}




$\begin{array}{ll}\text { AT1R } & \text { Angiotensin type 1 receptor } \\ \text { AT2R } & \text { Angiotensin type 2 receptor } \\ \text { GPCRs } & \text { G-protein-coupled receptors } \\ \text { TMPRSS2 } & \text { Transmembrane serine protease 2 } \\ \text { PAMPs } & \text { Pathogen-associated molecular patterns } \\ \text { US-FDA } & \text { US Food and Drug Administration } \\ \text { IL } & \text { Interleukins } \\ \text { BBB } & \text { Blood-brain barrier } \\ \text { BAL } & \text { Bronchoalveolar lavage } \\ \text { CNS } & \text { Central nervous system } \\ \text { GFAp } & \text { Glial fibrillary acidic protein } \\ \text { NfL } & \text { Neurofilament light chain } \\ \text { MRI } & \text { Magnetic resonance imaging } \\ \text { ICU } & \text { Intensive care unit } \\ \text { ARDS } & \text { Acute respiratory distress syndrome } \\ \text { PNS } & \text { Peripheral nervous system } \\ \text { RT-PCR } & \text { Real-time polymerase chain reaction } \\ \text { CSF } & \text { Cerebrospinal fluid } \\ \text { BCSFB } & \text { Blood-cerebrospinal fluid barrier } \\ \text { CP } & \text { Choroid plexus } \\ \text { PD } & \text { Parkinson's disease } \\ \text { OE } & \text { Olfactory epithelium } \\ \text { OECs } & \text { Olfactory ensheathing cells } \\ \text { EV } & \text { Extracellular vesicles } \\ \text { GCSF } & \text { Granulocyte colony-stimulating factor } \\ \text { DDC } & \text { DOPA decarboxylase } \\ \text { DMTs } & \text { Disease-modifying therapies } \\ \text { MS } & \text { Multiple sclerosis } \\ \text { A } \beta & \text { Beta-amyloid } \\ \text { AD } & \text { Alzheimer's disease } \\ \text { AMP } & \text { Antimicrobial peptide } \\ \text { hIPSCs } & \text { human induced pluripotent stem cells } \\ \text { NPCs } & \text { Neural progenitor cells } \\ \text { MHV } & \text { Mouse hepatitis virus } \\ \text { NTD } & \text { N-terminal domain } \\ \text { HR1 } & \text { Heptad repeat 1 } \\ \text { HR2 } & \text { Heptad repeat 2 } \\ \text { CP } & \text { Cytoplasmic domain } \\ \text { TM } & \text { Transmembrane domain } \\ \text { HT } & \text { Hydroxytyrosol } \\ \text { OLE } & \text { Oleuropein aglycone } \\ \text { OT } & \text { Ozone therapy } \\ \text { GBS } & \text { Guillain-Barre syndrome } \\ \text { ADEM } & \text { Acute disseminated encephalomyelitis } \\ & \end{array}$

\section{Introduction}

Coronaviruses (CoVs) are RNA viruses, which belong to the Coronaviridae family and Coronavirinae subfamily. They are widely distributed among animals and humans, causing respiratory, enteric, hepatic, and neurological disorders [1, 2]. SARSCoV, SARS-CoV-2, hCoV-229E, OC43, NL63, and HKU1 are currently circulating in the human population, causing mild and self-limiting upper respiratory tract infections [3]. Severe acute respiratory syndrome-coronavirus (SARS)-CoV and Middle East respiratory syndrome-coronavirus (MERS)-CoV have emerged as two highly pathogenic CoVs over the past two decades [4]. The outbreak of highly contagious SARS-CoV-2 is a variant of coronavirus, which is currently causing a pandemic infection globally. Infection with SARS-CoV-2 causes a severe respiratory disease referred to as the COVID-19, which is accompanied by the symptoms of fever, cough, pneumonia, dysphonia, and occasional diarrhea, after 3-14 days of incubation [5, 6]. As of April 6th 2021, over 131.8 million confirmed cases and 2.8 million deaths were reported worldwide due to COVID-19 disease (https://www.who.int.).

\section{Key Insights in to the Structural Features of SARS-CoV-2}

Structurally, SARS-CoV-2 is a $65-125 \mathrm{~nm}$ in diameter virus with club-shaped spikes on the enveloped surface. The virus contains a helical nucleocapsid, which is bound to a single positive-strand RNA of 27-32 kbp [7, 8]. Phylogenetic studies of the SARS-CoV-2 genome revealed its homology to other beta coronaviruses that were reported in bats. SARS-CoV-2 has a similarity of $79 \%$ to SARS-CoV and $50 \%$ to the MERS-CoV [9]. The genome of SARS-CoV-2 contains 14 open reading frames (ORFs) [10]. The ORF1a/ORF1ab is located at the 5' end and encodes two polypeptides, PP1a and PP1ab. Polypeptides upon proteolytic cleavage encode nonstructural proteins (Nsp 1-16) that form a replicase and transcriptase complex, which is required for replication and transcription of the virus $[11,12]$. The other 13 ORFs at 3 ' encode four main structural proteins and nine putative accessory factors. Structural proteins include: spike (S) protein, nucleocapsid (N) protein, membrane $(\mathrm{M})$, and envelope (E) proteins, which are essential for virus assembly and infection [13] (Fig. 1). "S" protein interacts efficiently with various host receptors and facilitates the attachment of the virus on the host cell surface and mediates the entry of the virus into the host cells. "M" protein maintains the virus in its intact shape [14]. "E" protein is the smallest structural protein that plays a significant role in the viral pathogenesis, viral assembly, and viral release inside the host cells [15]. "N" protein interacts with RNA substrates, transcriptional regulatory sequences, and genomic packing signals and plays a critical role in the pathogenicity $[16,17]$. The other essential structural and accessory proteins coded by the open reading frames are hemagglutinin esterase protein, $3 \mathrm{a} / \mathrm{b}$ protein, and $4 \mathrm{a} / \mathrm{b}$ protein [8]. Recent research reports have identified many mutations in the genome of SARS-CoV-2, suggesting the ability of viruses to acquire adaptations to their new host. The enhanced infection abilities of the SARS-CoV- 2 are believed to be imparted by mutations in NSP2 and NSP3 molecules [18]. 


\section{Mitigating SARS-CoV-2-Induced COVID-19 Disease: Strategies That Are Under Evaluation}

Several basic-, clinical-, and public health research findings have reported the efficacy of several molecules against the target proteins in SARS-CoV-2. Besides, several immunomodulators and drug repurposing strategies have been described as effective against SARS-CoV-2; however, their usage was constrained by adverse drug reactions and systemic toxicity. For instance, the administration of ACE-2 inhibiting anti-malarial drug hydroxychloroquine (HCQ) was proven effective against SARS-CoV-2-induced damage. However, monotherapeutic approaches using HCQ were reported unsuccessful, hence, strategies combining HCQ with other pharmacological agents for treating COVID-19 cases are currently being explored [19]. Also, several novel small molecule inhibitors (NSMIs), antiviral agents such as umifenovir, remdesivir, nitazoxanide, favipiravir, ritonavir, lopinavir, interferons (IFNs), anti-cytokine drugs, anticoagulants, and passive antibody therapies are currently being tested in different stages of clinical development (Table 1) [19].

\section{Key Therapeutic Targets}

\section{SARS-CoV-2 Interactions with Host Cells}

\section{Angiotensin-Converting Enzyme 2 (ACE-2)}

ACE-2 is a zinc-dependent metallocarboxypeptidase ectoenzyme, which is reported to be a key mediator of SARS-CoV-2 entry into host cells [39]. ACE-2 is located on the apical membrane of polarized cells of the testis, cardiovascular epithelium, cardiac myocytes, cardiac fibroblasts, epithelial cells of the kidney, liver, intestine, brain, and lungs [39-43]. ACE-2 is a type I integral membrane protein sharing $40 \%$ homology with ACE (angiotensin-converting enzyme). It is a key player in the renin-angiotensin system (RAS) [44]. ACE activates RAS by converting angiotensin I to angiotensin II. Angiotensin II activity is mediated through selective interactions with angiotensin II type 1 receptor (AT1R) and angiotensin II type 2 receptor (AT2R), a type of G-protein-coupled receptors (GPCRs). However, additional data is currently warranted to delineate the role of ACE in the entry of human CoVs [44].

ACE-2 acts as a functional cellular receptor for coronaviruses, namely, NL63 and SARS-CoV, by facilitating viral entry into the lungs $[45,46]$. Studies using fluorescent probes have confirmed that SARS-CoV-2 could act on the same ACE-2 receptor for entering the host cell [47, 48]. ACE- 2 consists of an $\mathrm{N}$-terminal peptidase domain and a
C-terminal collectrin-like domain joined together with a single transmembrane helix and an intracellular segment of about 40 amino acid residues $[49,50]$. The peptidase domain of ACE-2 cleaves angiotensin II to angiotensin (1-7), which functions in association with a G-protein-coupled Masreceptor. The ACE-2-angiotensin-Mas receptor axis mediates a regulatory effect, which antagonizes the effects of the ACE-angiotensin II axis and consequently protects the pulmonary and cardiovascular system from the harmful impact of RAS activation [51-53].

In the lungs, ACE- 2 is expressed in pulmonary endothelium, type I and type II alveolar epithelial cells, and smooth muscle cells [41]. Several studies have reported that the downregulation of ACE- 2 contributes to the development and progression of lung disease accompanied by the changes in vascular permeability, increased edema, neutrophil accumulation in lungs leading to respiratory failure, and death [52]. SARS-CoV-2 spike (S) protein binds to ACE-2, inducing ACE- 2 shedding by activating disintegrin and metalloproteinase-17 [54] (Fig. 2). S1 subunit has the receptorbinding domain, which upon binding to ACE-2, undergoes conformational changes facilitating viral attachment to the host [55]. S1 subunit in S-protein undergoes priming by the transmembrane serine protease 2 (TMPRSS2) or $\mathrm{pH}$ sensitive endosomal proteases cathepsin $\mathrm{B}$ and $\mathrm{L}$ at $\mathrm{S} 1 / \mathrm{S} 2$ and $\mathrm{S} 2$ sites. S-protein priming mediates the entry of SARSCoV-2 into the host, by the viral envelope and host cellular membrane fusion thereby triggers endocytosis [33, 56-58]. The enhanced binding affinity of SARS-CoV-2 to the ACE-2 receptor is due to a single N501T mutation in the gene coding for S-protein in SARS-CoV-2, which makes this disease transmission more likely to other organs [59].

The acidic environment in the endosomes is capable of facilitating the fusion of SARS-CoV-2 viral and endosomal membranes, releasing the viral genome to the cytosol [60]. The released positive-strand viral RNA is translated on host ribosomes into a replicase, which upon proteolytic cleavage yields proteins needed for genome replication. The full-length antisense negative-strand viral RNA template is generated by viral RNA-dependent RNA polymerase for replicating positive strands of viral genomic RNA and shorter subgenomic negative-strand RNAs [61]. Negative-strand viral RNA serves as templates for the translation of mRNAs in the endoplasmic reticulum that code for the structural proteins of the virus. In the endoplasmic reticulum, viral proteins get encapsulated and bud into membranes. Upon viral assembly, virions form vesicles are released through exocytosis [61].

ACE-2 gene polymorphism plays a crucial role in inducing severe lung damage, as it accounts for the differences in the ACE expression level in the general population [62]. ACE-2 polymorphism is identified by the insertion (I) or 


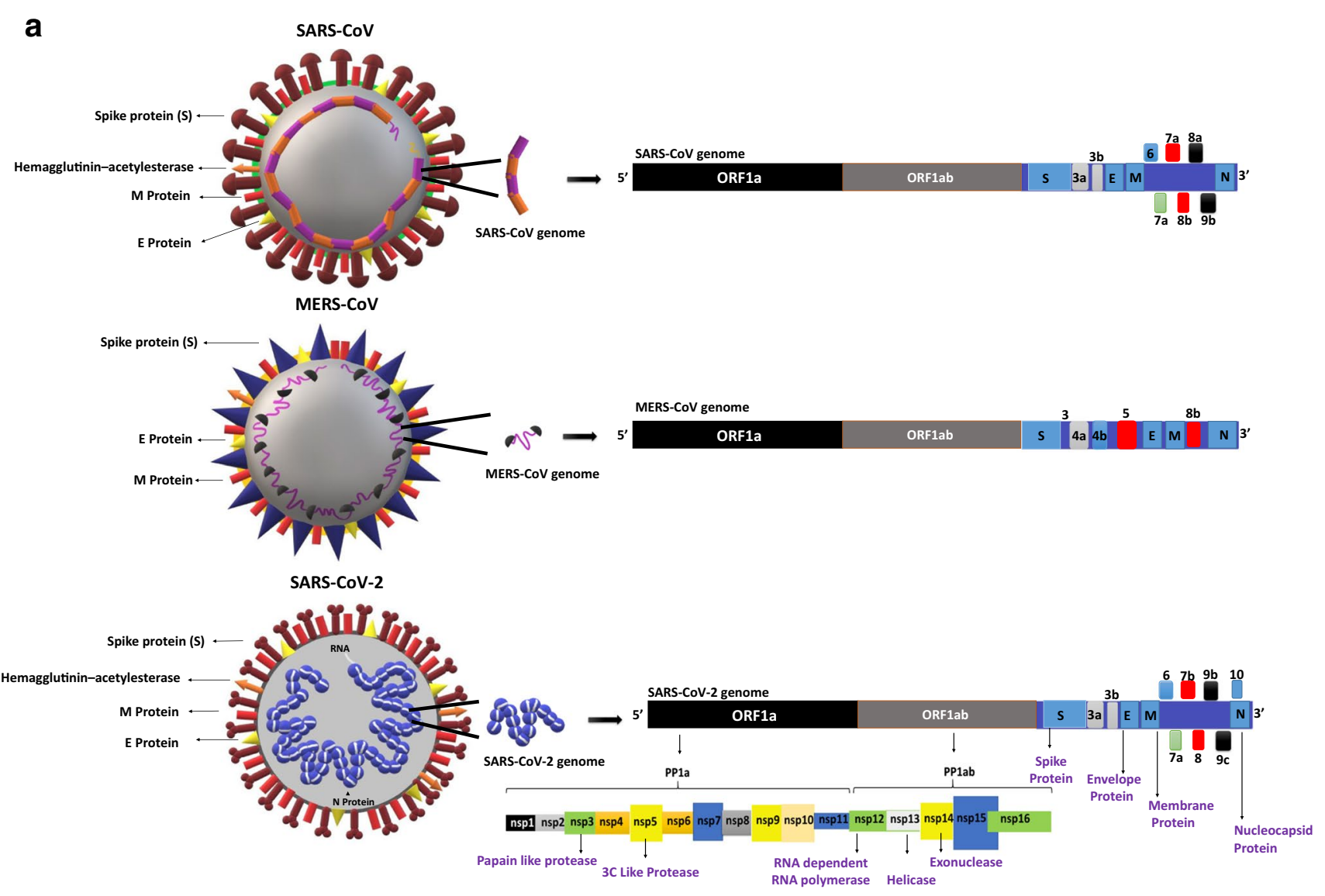

b

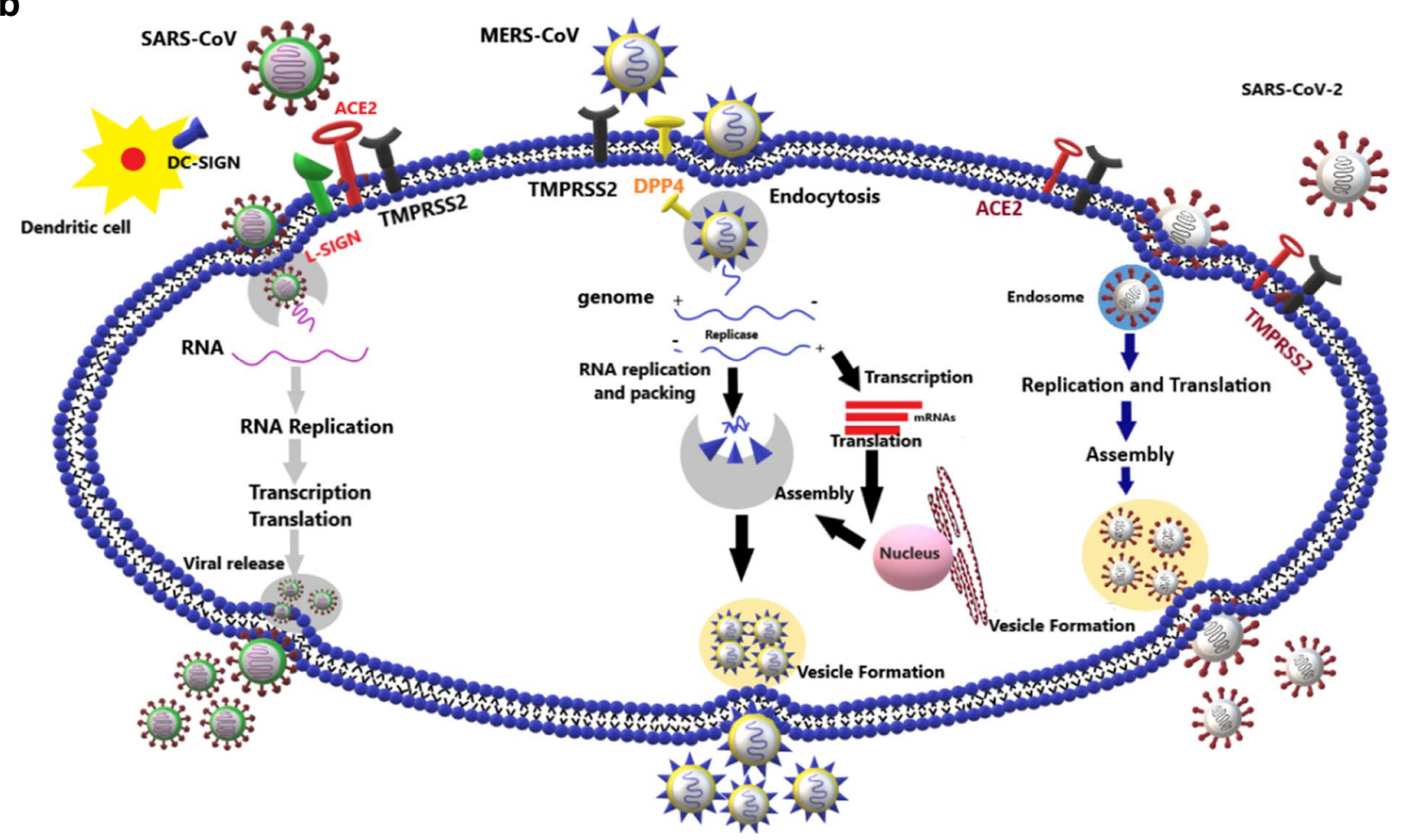


4Fig. 1 Genome organization of coronaviruses and variations in their mode of entry into human cells: a Structural representation and genome organization of SARS-CoV, MERS-CoV, and SARS-CoV-2: SARS-CoV-2 genome encodes four major proteins viz., spike (S) protein, the nucleocapsid $(\mathrm{N})$ protein, the membrane $(\mathrm{M})$ protein, and the envelope (E) protein. Total six open reading frames (ORFs), ORF3a, ORF6, ORF7a, ORF7b, ORF8, ORF10, and the polyprotein ORF1ab encodes several enzymatic proteins for the effective viral invasion of the host cells. b Host cell receptors and replication mechanism of SARS-CoV, MERS-CoV, and SARS-COV-2: the spike protein of the CoVs interacts with receptors on the host cell to make its entry. ACE-2 serves as a receptor for SARS-CoV and SARS-CoV-2. DCSIGN and L-SIGN serve as co-receptors for SARS-CoV. DPP4 serves as a receptor for MERS-CoV. CoVs replicate in the host causing cellular damage leading to further complications

deletion (D) of a $287 \mathrm{bp}$ Alu repeat sequence in intron 16 of the ACE gene [63]. Further studies are needed to assess ACE gene polymorphism in COVID-19 patients in the ongoing clinical trials using ACE-2 inhibitors and angiotensin II receptor blockers therapy.

ACE-2 is expressed in many other organs, hence, SARSCoV-2 is likely to enter tissues and organs through ACE-2 binding, causing multiple organ damage including kidney injury, cardiac injury, liver dysfunction, and cerebral damage [41, 64-66] (Fig. 3). The current understanding of the pathogenic mechanisms of SARS-CoV-2 binding to ACE-2 in the brain, liver, kidney, and heart are poorly described, hence, further studies are warranted.

Addressing this gap, recent studies have shown that in the brain, ACE-2 is expressed in glial cells and neurons, suggesting the neurotrophic potential of SARS-CoV-2, entering through circulation or an upper nasal transcribrial route causing cerebral damage [64]. More research studies are required to elucidate the specific mechanisms behind neuronal damage mediated by SARS-CoV-2 infection (Fig. 3).

In addition to the brain, ACE- 2 is expressed in hepatocytes of the liver, and bile duct cells consequently invoke damage to the liver [67]. Moderate microvascular steatosis, mild lobular, and portal activity were observed in biopsies of COVID-19 individuals [65]. Nevertheless, a mechanism underlying the liver dysfunction needs to be explored further, as the injuries could be caused by SARS-CoV-2 infection or antiviral drugs used during the treatment [65]. For example, several recent studies have shown that the antiviral drugs lopinavir/ritonavir causes injury to the liver [68]. Addressing this aspect will help to develop better strategies for mitigating SARS-CoV-2-induced liver damage (Fig. 3).

The kidney is another organ with elevated ACE-2 expression. The renal tubular cells are known to express high levels of ACE-2 [69]; however, no research evidence has been reported for the SARS-CoV-2 invoked kidney injury. In a statistical survey of 1099 COVID-19 patients, $0.5 \%$ reported acute kidney injury with a severity rate of $83.3 \%$. In some COVID-19 patients, SARS-CoV-2 was detected in the urine [69]. Additional studies are immediately warranted to test whether SARS-CoV-2 infections cause kidney damage, if so, the mechanisms involved in such cellular damage. Further, it is currently unknown whether urine collected from

Table 1 Therapeutic strategies to target ACE-2 receptor and S-protein interaction in SARS-CoV-2 infection

\begin{tabular}{lll}
\hline Type & Target & Description \\
\hline Synthetic compounds & & \\
RS504393 & ACE-2 and S-protein of SARS-CoV-2 & Treated for lung injury and bronchial wall thickening [20] \\
KT185 & S-protein of SARS-CoV-2 & Anti-inflammatory [21] \\
TNP & ACE-2 & Tyrosine kinase inhibitor [22, 23] \\
GNF-5 & ACE-2 & Kinase inhibitor [24] \\
GR127935 hydrochloride hydrate & ACE-2 & Vasoconstriction monitoring [25] \\
Eptifibatide acetate & ACE-2 & Protects lung injury and inflammation [26] \\
Monoclonal antibody & & \\
$47 D 11$ & Entry of SARS-CoV-2 & Human antibody specific to SARS-CoV-2 [27] \\
Antiviral agents & & \\
HrsACE-2 & ACE-2 & Recombinant protein [28] \\
CR3022 & S-protein & Neutralizing antibody [29] \\
Umifenovir (Arbidol) & Endocytosis & Membrane fusion inhibitor [30, 31] \\
EK1C4 & Endocytosis & Pan-coronavirus fusion inhibitor [32] \\
Camostat mesilate & TMPRSS2 & Serine protease inhibitor [33, 34] \\
Nafamostat & TMPRSS2 & Serine protease inhibitor [30, 35] \\
Bromhexine hydrochloride & TMPRSS2 & Mucolytic drug [36] \\
PAI-1 & TMPRSS2 & Serine protease inhibitor [37] \\
Chloroquine & Cell fusion/virus & Drug for autoimmune disease [38] \\
\hline
\end{tabular}




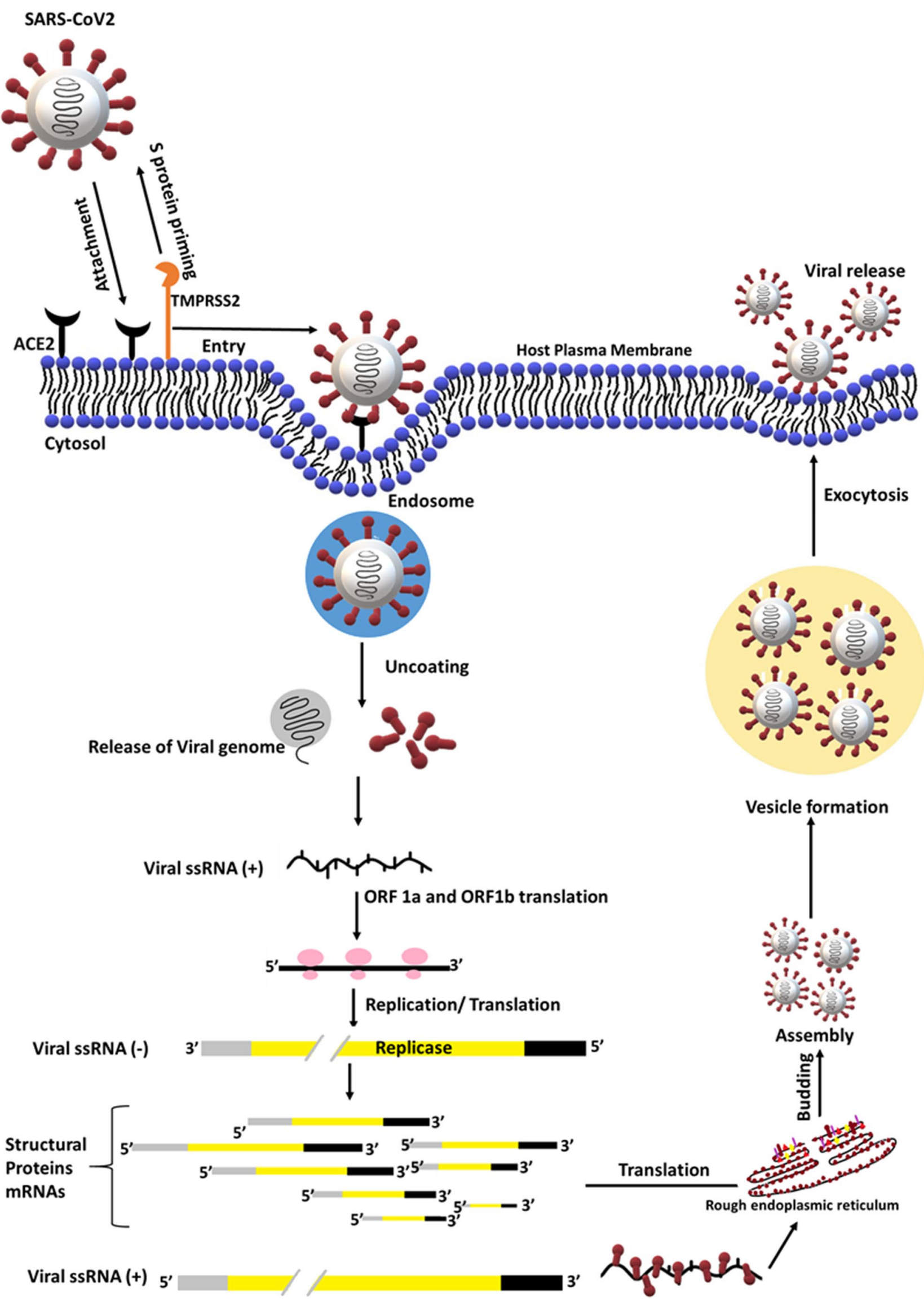


4Fig. 2 Interaction of SARS-CoV-2 with ACE-2 receptors in lungs: the lysosomal proteases, such as elastase, and cell surface proteases TMPRSS2 could induce activation of SARS-CoV-2 S-protein for membrane fusion through ACE-2 receptors, which consequently causes lung tropism through endosome formation, multiple virion replication, and exocytosis

COVID-19 patients could also be used to detect SARSCoV-2. Establishing methods to detect SARS-CoV-2 in urine will help in minimizing the distress caused due to nasal/throat sample collection (Fig. 3).

In the case of heart, SARS-CoV-2 follows the mechanisms similar to SARS-CoV to trigger cardiovascular complications [70]. ACE-2 expressed in cardiomyocytes is capable of interacting with SARS-CoV and fosters the extensive levels of Ang-II, consequently promoting cardiovascular abnormalities [70]. But it is currently unknown whether SARS-CoV-2 can also directly infect cardiomyocytes.

ACE-2 expression is also detected in exocrine glands and islets of the pancreas. ACE-2 expression in the pancreas is slightly higher compared to the lungs, indicating the possibility of binding of SARS-CoV-2 to ACE-2 in the pancreas, causing severe pancreatic injury [71].

Studies have reported coagulation and fibrinolysis in COVID-19 patients, which is due to the activation of host defense mechanisms to limit the spread of the virus upon infection [72]. The initial phase of viral infection triggers a systemic inflammatory response characterized by an elevated level of cytokine activity and generation of thrombin and fibrinogen [72]. This response induces the expression of tissue factors, which initiate the coagulation. The measurement of coagulation and fibrinolysis factors in bronchoalveolar lavage (BAL) fluid showed elevated thrombin levels and the suppression of fibrinolysis, indicating the pathogenesis of respiratory distress. Furthermore, massive endothelial cell apoptosis, which is caused by vascular endothelial damage upon SARS-CoV-2 infection contributes to procoagulant changes in COVID-19 [72]. Recent studies have shown thrombocytopenia in COVID-19 patients, but the mechanism of SARS-CoV-2 involvement is still unclear [73] (Fig. 3).

\section{Cytokine Storm}

Innate- and acquired-immunity mediated antiviral responses triggered by recognizing pathogen-associated molecular patterns (PAMPs) and induced antigen-specific adaptive immunity are the key defense systems that protect the host organisms from devastating effects of infections [74, 75]. The response to viral infections depends on the release of cytokines, chemokines, leukotrienes, proteases, reactive oxygen species, and the rate of viral clearance [76]. The balance between the antagonistic signals and cellular reactions influences the immune response to pathogens by preventing damage to host tissues. As a result, the activated immune system returns to a resting state and prevents the damage, which is otherwise caused by continuously activated host immune reactions [76]. Excessive synthesis of cytokines in response to viral infections results in an acute and severe systemic inflammatory response known as "cytokine storm," which causes multi-organ damage [76]. Studies have shown that IL- 6 and IL-17 are predictive of disease severity and correlate with respiratory failure [77]. Potential therapeutic strategies targeting IL-17 alone or in combination with IL-6 for COVID-19 are currently under investigation. Tocilizumab, which targets IL-6, is currently approved by the United States Food and Drug Administration (US-FDA) for treating COVID-19 patients [78].

\section{SARS-CoV-2-Induced Neurological Complications}

The SARS-CoV-2 primarily affects pulmonary, cardio-, and renal functions [79]. However, recently it has been reported that SARS-CoV-2 can cause secondary complications on other systems as well [79]. Neurological complications are one such set of complications that require more attention to develop novel therapeutic modalities. Frequently, SARSCoV-2 infections-induced neurological disorders are combined with either pre-existing metabolic abnormalities such as diabetes, other infections, or chronic- to acute inflammatory episodes of the nervous system [80]. However, it is currently not clear whether all COVID-19 patients develop neurological complications or only a portion is prone. Therefore, it is important to know the signs and features of susceptible individuals who are at risk for developing neurological infections.

\section{Routes of SARS-CoV-2 Entry into the Nervous System}

The SARS-CoV-2 virus, which enters the bloodstream can spread into the central and peripheral nervous systems (PNS) via retrograde axonal transport or by infecting the pericytes and astrocytes, which are the central part of the blood-brain barrier (BBB) [81]. Neuro-invasion of SARS-CoV-2 may also be mediated through the olfactory nerve or infection of vascular endothelium or by infected leukocyte migration across the BBB. Once the virus enters CNS through the conceded BBB, the SARS-CoV-2 can be distributed along the neurotransmission or hematogenous pathways that include serotonergic dorsal raphe system and Virchow-Robin spaces, respectively. The neuro-invasive potential of SARS-CoV-2 predominantly relies on the medullary structures interacting with the brain stem, accompanied by the respiratory system. This could be one of 


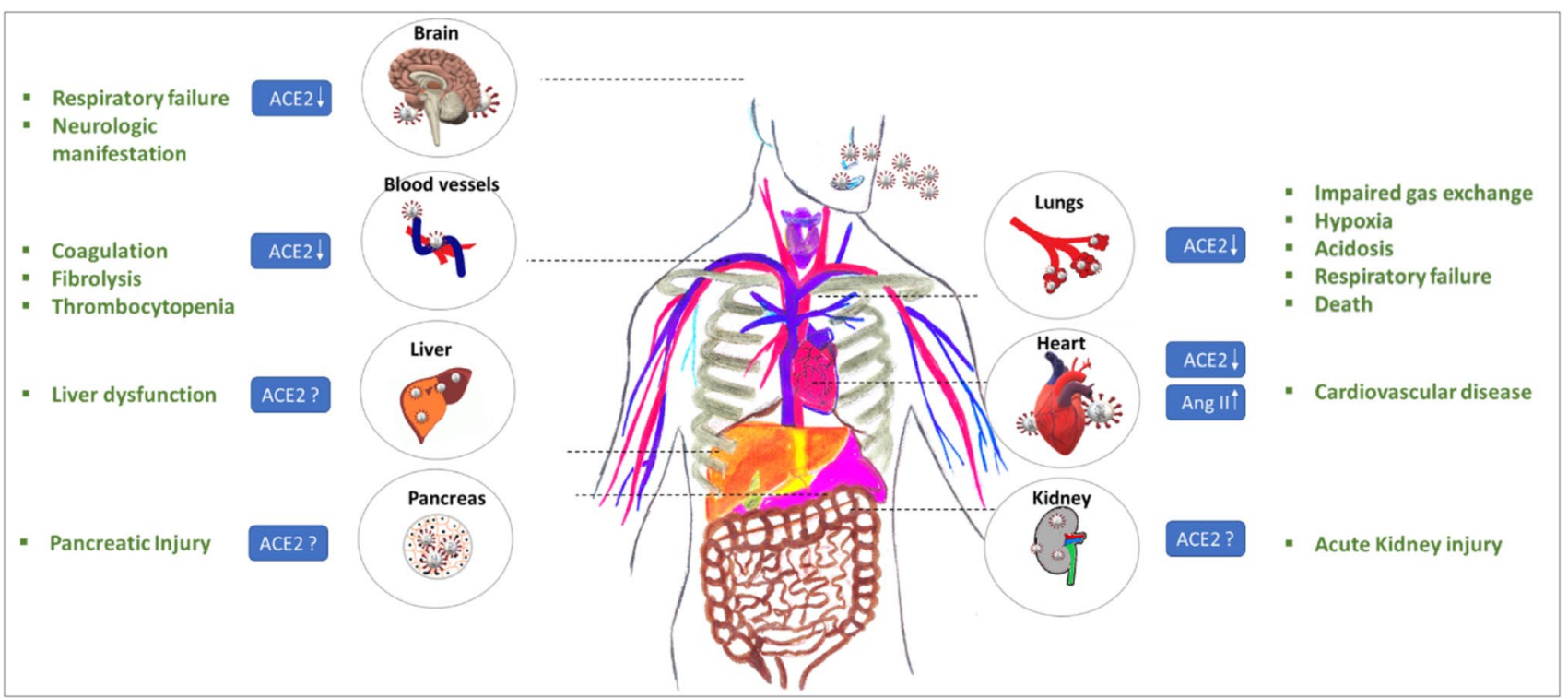

Fig. 3 Multiple organ dysfunctions induced by the interaction of SARS-CoV-2 with host cell ACE- 2 receptors. The figure represents multi-organ dysfunction which is characterized by acute kidney

the conducive factors responsible for the high incidence of respiratory failures in COVID-19 patients [81].

The neurological effects of COVID-19 are due to either direct viral entry or indirect infection into the CNS [82, 83]. Epidemiological studies have shown that the latency of 1-week gap between the initial infection and severe infection for COVID-19 patients provides space sufficient for potential viral entry into the CNS [84]. Neurotropism activity is commonly detected in coronaviruses; neuro-invasive properties are well documented in SARS-CoV, MERS-CoV, HCoV229E, and HCoV-OC43 [85-87]. Further, the spike protein of SARS-CoV-2 alters the blood-brain barrier (BBB) function, which provides an additional mechanism of potential CNS entry [88]. The conserved viral structure and genetic similarity of SARS-CoV-2 with SARS-CoV provide further evidence that the virus can enter into the CNS $[89,90]$.

Kanberg et al. reported CNS damage in COVID-19 patients by measuring the variations in serological biomarkers. For instance, elevated plasma glial fibrillary acidic protein (GFAp) and neurofilament light chain (NfL), which are the markers of astrocytic and neuronal injury, were reported in 47 COVID-19 patients [91]. The authors of this study demonstrated a significant increase in GFAp and NfL in 18 patients with severe COVID-19; however, GFAp levels were reported to decrease upon treatment follow-up. But a continuous increase in NfL level was reported throughout the treatment. Similar to severe COVID-19 cases, an increase in the levels of plasma GFAp was also reported even in 9 patients with moderate COVID-19 [91]. But no treatment follow-up status is reported in this study. This phenomenon is evident injury, respiratory failure, liver failure, neurological complications, and cardiovascular disease upon SARS-CoV-2 infection

in astrocytes' early involvement and delayed axonal injury in the CNS due to COVID-19 infection [91].

Coolen et al. have provided evidence of central nervous system involvement in COVID-19 patients [92]. Authors of this study have performed magnetic resonance imaging (MRI) on COVID-19 patients within $24 \mathrm{~h}$ of death and showed parenchymal abnormalities, including white matter changes, posterior reversible encephalopathy syndrome, and hemorrhage in four individuals [92]. This could be due to the breakdown of the BBB and COVID19 based endothelial abnormalities, irrespective of SARSCoV-2 virus infection in endothelial cells. The study also showed an indication of olfactory bulb unevenness and anosmia in four other patients [92]. A study conducted in Strasbourg, France, on the neurological function of 58 COVID-19 patients with acute respiratory distress syndrome (ARDS) admitted into the intensive care unit (ICU) was assessed and showed neurological abnormalities in the $8 / 58$ patients $(\sim 14 \%)$ during admission to the ICU. However, 67\% (39/58) patients exhibited profound neurological signs while $69 \%$ (40/58) of patients exhibited agitation after the withdrawal of sedation or a neuromuscular blocker. Also, approximately 45\% (26/58) of patients were characterized by a state of confusion, while 67\% (39/58) of patients reported exhibiting corticospinal tract signs. Serendipitously 13 patients $(22.41 \%)$ exhibited encephalopathic features followed by leptomeningeal enhancement in (8/13) patients and bilateral frontotemporal hypoperfusion (11/13) in MRI scans. Follow-up clinical studies were performed on 45 patients in which 15 patients 
typically exhibited dysexecutive syndrome followed by the presence of in-attention, disorientation, alterations in movements, and responses [93]. A research study on 214 COVID-19 patients from Wuhan, China, delineated severe SARS-CoV-2 infection in 41.1\% (88/214) patients. The remaining had non-severe infection $(58.9 \%$; 126/214); among them $36.4 \%(78 / 214)$ of patients had orchestrated distinct neurologic signs due to damage to sensory neurons that consequently foster defects in sensations of olfaction and gustation and invoke neuropathic pain, seizures, and strokes [83]. Furthermore, these defects were more evident in COVID-19 patients across the world [83].

Based on the symptoms, neurological manifestations underlying the COVID-19 were segregated into skeletal, muscular injury indexes, and CNS indexes [94]. Among these neurological manifestations, acute cerebrovascular disease, headache, dizziness, ataxia, defects in consciousness, and seizures were reported as critical ones. For instance, the SARS-CoV-2 infection invoked alterations in the peripheral nervous system (PNS) as indicated by nerve pain, impaired taste, smell, or vision [6]. Results of this study showed that 78/214 patients exhibited neurological abnormalities exhibiting symptoms related to CNS dysfunction, skeletal muscle injury, and defects in PNS function [83]. All these neurological symptoms were predominantly reported in older patients [60 years or above], who had existing co-morbid conditions viz., hypertension, diabetes, chronic malignancy, and cerebrovascular diseases [95-98].

A plethora of recent research reports depicted that the ACE-2 receptor extensively plays a crucial role in SARS$\mathrm{CoV}-2$ virus entry into the host body. This protein is also widely reported in CNS, predominantly in the brainstem and subfornical organ, paraventricular nucleus, nucleus of the tractus solitarius, and the rostral ventrolateral medulla regions [99]. These regions of the brain are known to control cardiovascular functions [99]. ACE-2 expression is also reported in neurons and astrocytes [99]. Li et al. deciphered that COVID-19 infection could induce changes in gut microbial composition and invoke neuropathogenesis which confers neuropsychiatric symptoms through the gut-brain axis [100].

Initial studies using RT-PCR depicted the extensive ACE-2 expression in the brain [101], but ACE-2 immunoreactivity was typically reported in the brain endothelial and smooth muscle cells [102]. The expression of ACE-2 in glial cells $[99,103]$ concludes that brain tissue could be a potential target for SARS-CoV-2. SARS-CoV-2 RNA was evident during CNS infection indicating the possibility of direct infection of CNS by SARS-CoV-2.

The COVID-19 patients with meningitis exhibit seizures, hippocampal atrophy, and pan-paranasal sinusitis [104]. A recent case study showed the existence of SARS-CoV-2 virus in the CNS of a 56-year-old encephalitis patient who had reported mitigation of consciousness. These findings in COVID-19 patients are in line with past reports with HCoV-OC43 infected patients [105]. Likewise, SARS-CoV was observed in CSF from SARS patients with persistent epilepsy [106]. A retrospective study of COVID-19 patients showed acute ischemic stroke, cerebral venous sinus thrombosis, and cerebral hemorrhage [83]. Hence, it was concluded that the SARS-CoV-2 exhibits a capacity to bypass the respiratory tract and the capability to confer infection in other tissues, which could be a critical feature of the SARSCoV-2 virus.

\section{SARS-CoV-2 and a Robust Mitochondrial System and Immune-Competency Rely on Hormesis}

Recent studies have shown the ability of SARS-CoV-2 to impair autophagy and block mitophagy [107]. This effect is similar to SARS-CoV, which is capable of mitochondrial fusion, impairs mitophagy, and induces cell death $[108,109]$. Studies are currently investigating the SARSCoV-2-induced modulation of mitochondrial- and immune system changes by unraveling the modulation of the viralmediated inflammasome. Irisin, a muscle-derived hormone, is reported to protect mitochondria and ischemia/reperfusion injury in the lung during exercise [110]. But it is unknown whether SARS-CoV-2-induced mitochondrial dysfunctions are mediated by irisin modulation. Furthermore, studies have demonstrated that irisin could facilitate changes in the genes in adipocytes that are affected by SARS-CoV-2 and neutralize the ROS in macrophages thereby display antioxidant and anti-inflammatory properties [111, 112]. Since mitochondria play an important role in immune response, and several viruses can modulate mitochondrial function, it is presumed that SARS-CoV-2-induced effects could also be mediated through the dysregulation of mitochondrial function [109]. The altered mitochondrial function might be a variant process, which occurs in SARS-CoV-2-mediated pathophysiology [113]. Several immune cells possess mitochondria and are now embraced by the "immunometabolism concept" [114, 115]. However, age and lifestyle are two crucial factors that determine susceptibility to the virus based on hormetic-like preconditioning [115]. Any "virusinduced exogenous hormetic stimuli" could be mitigated by the recurrent physical activity consequently decreasing the viral-mediated mitochondrial stress [116-118]. Preconditioning signal through hormone-like irisin by the physical activity is leading to cellular protection via hormesis, which is an important redox-dependent anti-inflammatory and anti-oxidant-associated mechanism [113]. Thus, mitochondrial hijacking and hormetic-like preconditioning through SARS-CoV-2 could be considered as a significant factor in the pathophysiology of neuroinflammation [113]. 
SARS-CoV-2 is reported to enhance aerobic glycolysis (Warburg shift) to promote replication, which is a strategic tactic used by many viruses (similar to cancer cells) via metabolic reprogramming [119]. For instance, melatonin can impair this metabolic reprogramming mediated by SARS-CoV-2, hence, melatonin could be considered as the powerful antioxidant which can protect mitochondria [120,121]. This kind of divergent SARS-CoV-2 signaling should be unraveled in neuronal cells by studying the melatonin-induced mitochondrial antioxidant system [121]. Several viruses including SARS-CoV-2 can modulate mitochondrial bioenergetics and redox function in both immune systems and acquire the capability of infecting other cells to enhance their replication, which consequently fosters viral-mediated pathophysiology due to extensive oxidative stress [121]. Hormetic dose-response of novel anti-viral molecules may provide the central underpinning of neuroprotective responses against viral infections. The study of hormetic dose-responses is crucial to illustrate the cellular defense pathways including sirtuin and Nrf-2 related signaling cascades about SARS-CoV2-induced neuronal diseases [122]. Furthermore, it is crucial to unravel the underlying viral-mediated pathophysiology as SARS-CoV-2 may modulate the functions of neuronal mitochondria to generate oxidative stress. As mitochondria-mediated aging is associated with dysregulated metabolism and requires novel therapeutic modalities viz., mitochondrial anti-oxidants and anti-inflammatory molecules are likely to correct these dysregulated metabolic and physiological processes before the administration of vaccines against SARS-CoV-2-induced neuropathology [123]. "Hydroxytyrosol (HT)-rich aqueous olive pulp extract (HIDROX®)" has been reported to mitigate SARS-CoV2-induced pathophysiology by inducing potent virucidal activity [124]. Hydroxytyrosol (HT) and oleuropein aglycone (OLE) are two potential molecules reported being beneficial to mitigate the pathophysiology of neurodegeneration [124]. Hormesis and anti-oxidant nature, which enhances the activity of proteasome and phase II detoxifying enzymes, are potential mechanisms of action by which these pharmacological molecules work against SARS-CoV-2-induced neuropathophysiology [125, 126]. In addition to the above therapies, the vaccinomics approach might be useful to mitigate the complications accelerated with immunosenescence factors against SARS-CoV-2 in the infected individuals over 65 years of age $[123,127]$. Additional studies are warranted to prove the role of vaccinomics-based approaches for reducing the complications of SARS-CoV-2 infections.

\section{Mechanism of Infection of Central Nervous System (CNS) and Peripheral Nervous System (PNS) by SARS-CoV-2}

Extensive scientific evidence now proved that COVID-19 can cause many neurological complications [128]. Also, neurological complications have attracted widespread attention among researchers to delineate the short- and long-term impact on population health during COVID-19 infections [129]. Yet, in-depth studies are required to ascertain the underlying mechanisms/pathways involved in the COVID-19 induced neuronal complications.

\section{Indirect Entry}

SARS-CoV-2 may enter the nervous tissue through retrograde and anterograde transport along with peripheral nerves [130]. Existing data showed that SARS-CoV-2 can infect the olfactory bulb through TMPRSS2 and ACE-2 receptors $[131,132]$. Once infected, the transfer of virus may occur through extracellular vesicles (EVs) in the olfactory ensheathing cells (OECs), independent of the ACE-2 receptors. In addition to the olfactory nerve, the virus can migrate via the trigeminal and vagus nerves [130].

SARS-CoV-2 may invade the nervous tissue through the ACE- 2 or TMPRSS2 receptors. Since, ACE- 2 receptors are also expressed on the membrane of the spinal cord, the virus may invade the spinal cord through its binding to the ACE-2 receptors on the surface of peripheral neurons. The virus can penetrate the cribriform plate located closely to the olfactory bulb and the olfactory epithelium (OE), thereby enters the CNS system indirectly. Anosmia or hyposmia are considered as novel complications of COVID-19 patients to confirm this route of infection [133].

COVID-19 induced neural infection is accompanied by the uptake of the virus into the ciliated dendrites/soma [134]. The virus could effectively enter via anterograde axonal machinery transport along the olfactory nerve [134]. Moreover, the virus can also infect and cross non-neuronal olfactory epithelium cells and directly enter the CSF around the olfactory nerve bundles [135]. ACE-2 and TMPRSS2 receptors of these cells could propagate the infection in elderly individuals, which may be considered as the higher risk of SARS-CoV-2 accumulation in OE cells [135] (Fig. 4).

\section{Direct Pathway}

Even though it is now confirmed that SARS-CoV-2 infection leads to neurological complications, the direct entry of the SARS-CoV-2 into the nervous system and its exact microinvasion are yet to be unraveled. For instance, the virus may directly confer invasion of brain tissues as indicated by the presence of nucleic acid materials in both CSF and brain tissue [130]. This kind of viremia occurred through a direct pathway likely to provoke virus transcytosis across the endothelial cells of the blood-brain barrier (BBB) of the brain or the virus infection across the epithelial cells of 


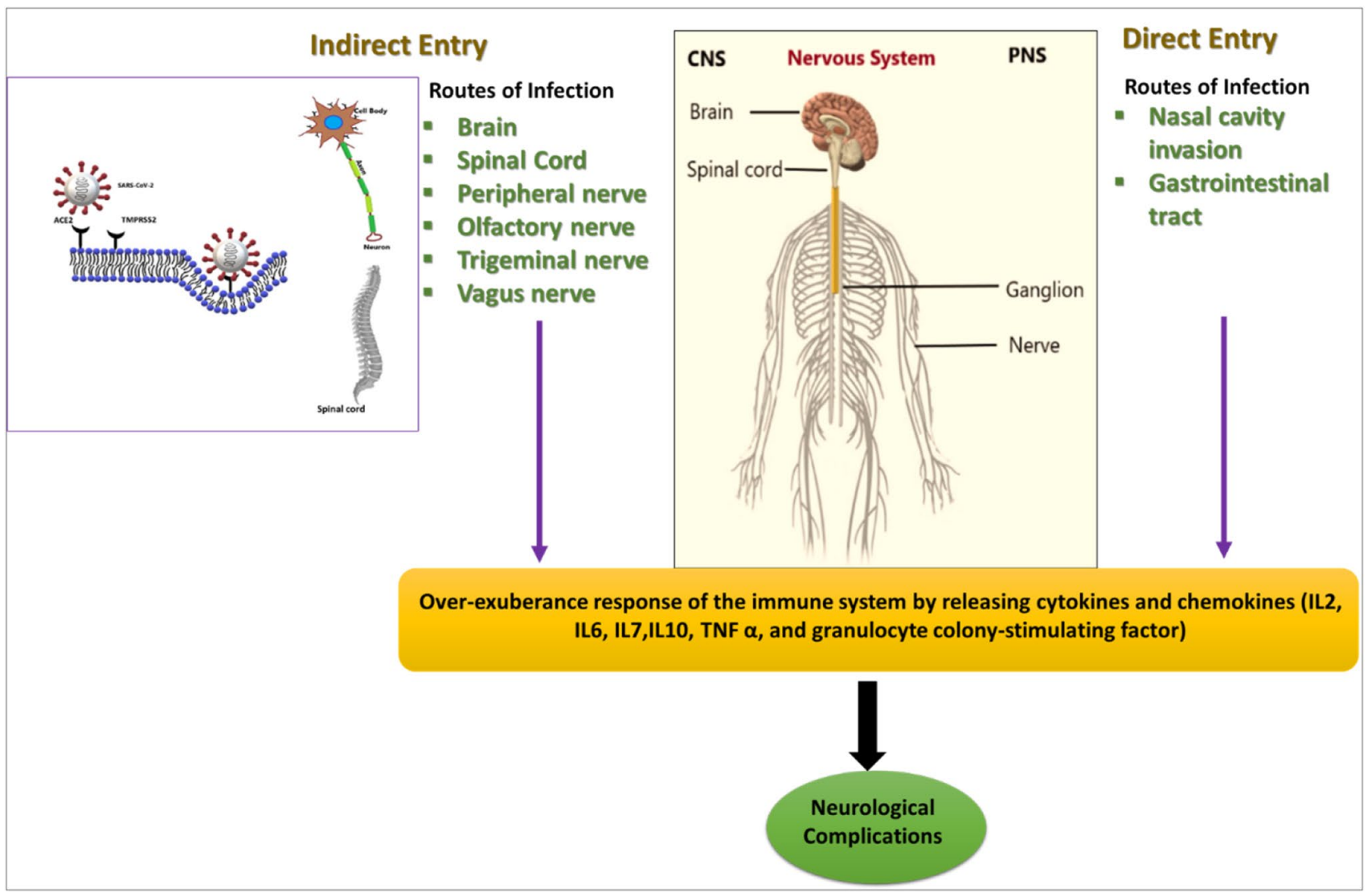

Fig. 4 Overview of SARS-CoV-2 entry in the nervous system. SARS-CoV-2 virus is reported to infect CNS and PNS by direct and indirect pathways. This results in the generation of cytokines and

the blood-cerebrospinal fluid barrier (BCSFB) in the choroid plexus $(\mathrm{CP})$ of brain ventricles. Besides, the leukocytes may also act as a vector to transport the virus across the BBB [136, 137]. The Braak hypothesis says that an invasive neuro-virus could enter the CNS through the nasal cavity and the gastrointestinal tract [138] (Fig. 4).

\section{COVID-19 Induced Neuroinflammation}

One of the significant neuropathological mechanisms of SARS-CoV-2 infection is the induction of a hyperinflammatory state in infected individuals [66]. The over-exuberance response of the immune system could foster the generation of cytokines and chemokines viz., interleukins 2 , 6,7 , and 10, TNF $\alpha$, and granulocyte colony-stimulating factor (GCSF) [139]. These cytokines and chemokines provoke extensive activation of neuroinflammatory cascades and drive neuronal hyperexcitability via glutamate receptor activation followed by induction of seizures [140, 141]. An inflammatory theory of SARS-CoV-2 infection was also supported by the steroid response of COVID-19 patients comorbid with severe encephalitis [142]. chemokines by elevating the immune response and causing severe neurological complications

Over-exuberance response of the immune system in SARS-COV-2 infection may cause inflammatory injury and brain edema, which consequently induce defects in consciousness [143]. Inflammatory and immunologic responses further amplify the cytokine storm [144]. Intracranial cytokine storm potentially confers BBB breakdown and leading to the migration of leukocytes. During this condition, the virus is failed to exhibit the potential of direct invasion or para-infectious demyelination [130].

It has been reported that COVID-19 patients experience defects in gustation (sense of taste) and olfaction due to direct damage to the olfactory bulb leading to inflammation in the nasal cavity. This inflammation blocks binding of odorants to the olfactory receptors thereby affect the olfactory responses [145]. Regeneration and repair of damaged neurons during COVID19 take a longer time within the olfactory bulb [145]. Similarly, COVID-19 led to the dysfunction of taste buds thereby cause ageusia (loss of taste function of the tongue) [146]. In acute phases of this infection, the loss of olfaction could be due to nasal inflammation and mucosal edema. These symptoms may persist for months to years due to extensive olfactory insult triggered by the virus [145]. 


\section{Impact of COVID-19 on Neurological Disorders}

COVID-19 pandemic exhibited numerous short-term and long-term adverse effects on a large group of elderly people with neurological disorders and neurodegenerative diseases [147]. For instance, Parkinson's disease (PD) is one of the devastating neurological diseases, which occurs due to the defects in the mesolimbic system of basal ganglia [148]. PD patients infected with COVID-19 exhibit adverse effects that include motor symptoms, such as tremors, freezing of gait, or dyskinesias [149], and diminished dopaminergic medication efficacy [150-152]. Thus, the COVID-19 pathophysiology and alteration in the dopamine synthesis pathway have been hypothesized. Recent reports have demonstrated the co-expression of dopa decarboxylase (DDC), a significant enzyme of both dopamine and synthetic serotonin pathways, and ACE-2 receptor [153]. SARS-CoV-2 binding with ACE-2 has been reported to invoke a downregulation of ACE-2 [154]. The possible functional connection between ACE-2 and DDC indicates the alterations in dopamine synthesis, which further confer PD-related complications [153]. An imbalance in dopamine levels can worsen the severity of PD. In addition to the impact of COVID-19 on PD patients, the virus may invoke sporadic PD during infection. For instance, ACE-2 is reported to be involved in co-regulating the dopa decarboxylase (DDC) during dopamine synthesis; any SARS-CoV-2-induced downregulation of ACE-2 expression would invoke alterations in both serotonin and dopamine pathways, which are significant pathways involved in PD pathophysiology $[53,153]$. Hence, it is hypothesized that the SARS-CoV-2 can effectively induce alterations in dopamine during defective expression of ACE-2 and DDC [153].

Multiple sclerosis (MS) is another neurological complication reported to be worsened by SARS-CoV-2 infection. The mortality/morbidity risk was reported to be relatively low with disease-modifying therapies (DMTs) in the MS patients suffering from COVID-19 infection. Furthermore, the intake of immunomodulatory drugs in these patients could invoke low pulmonary capacity, which further enhances the risk of COVID-19 related pneumonia [155]. Hence, the decision to avoid the intake of DMTs in COVID-19 patients comorbid with MS relies upon several miscellaneous factors viz., immunomodulation, and disease severity. Complications of COVID-19 infection are much higher due to the over-reaction of the immune system to the SARS-CoV-2. However, further studies are warranted to decipher the molecular pathways to be targeted to mitigate the complications. Furthermore, the establishment of appropriate preclinical animal models would help in developing better therapeutic agents for combating COVID-19 induced complications in individuals suffering from MS [156-158].
SARS-CoV-2 infection may also invoke a severe neurodegeneration process, which could reduce the overall survival of COVID-19 patients with Alzheimer's disease (AD) [130]. But, currently, no evidence suggests a correlation between COVID-19 and AD development [159]. One of the key factors responsible for AD induction is the accumulation of amyloid-beta plaques (A $\beta$ plaques) in the brain $[160,161]$. $A \beta$ is produced from the enzymatic processing of amyloid precursor protein (APP). An intriguing relation between viral infections and $A \beta$ has been delineated by several researchers and the data supports that $A \beta$ is an antimicrobial peptide (AMP) [162]. The whole-brain homogenates obtained from AD patients compared to the age-matched non-AD samples suggested a strong correlation between AMP action and A $\beta$ levels [162]. However, the extensive anti-microbial activity of $A \beta$ was ablated in the models of immune depletion of AD brain homogenates, who were subjected to treatment with anti-A $\beta$ antibodies. Transient infection with SARS-CoV-2 virus could either initiate or accelerate $A \beta$ accumulation inside the brain and cause AD [159] Further, a positive inflammatory response was stimulated through transient viral infection inside the CNS, which may foster the abnormal self-perpetuating innate immune responses due to the severe cerebral $\mathrm{A} \beta$ stagnation [159]. Neuroinflammation is another early characteristic of AD. CNS tropism of the virus across brain tissues expressing ACE- 2 can induce ACE-2 expression, which may enhance the risk of virus invasion and activate molecular processes that invoke neurodegeneration [159]. However, these molecular mechanisms in SARS-CoV-2 infection are yet to be unraveled to delineate the viral-induced alterations in neurodegeneration.

\section{SARS-CoV-2-Associated Neurological Diseases}

\section{Guillain-Barré Syndrome (GBS) and SARS-CoV-2}

Guillain-Barré syndrome (GBS) is an inflammatory polyradiculo-neuropathy and it is associated with several viral infections [163]. The incidence of GBS is considered to be the most significant aspect in the SARS-CoV-2 infected patients as GBS could confer respiratory failure, which is the most devastating complication observed with SARS-CoV-2 infection [164]. The other disease complications of GBS are flaccid paralysis, sensory abnormalities, and autonomic dysfunction due to autoimmune-mediated pathophysiology [165].

GBS in a COVID-19 patient was first reported in Wuhan, China, where demyelination of motor and sensory nerves was detected with a prolonged distal latency [166]. It is caused due to the cross-reaction of antibodies produced by the host against the viral infection, binding to peripheral nerves causing neuronal dysfunction [167]. 
Reports suggested symptoms like facial and limb paresis (a muscular weakness caused due to nerve damage), paresthesia, and immune-inflammatory responses were evident in SARS-CoV-2-mediated neuronal pathophysiology in GBS patients [168]. For instance, a variant of GBS Miller Fisher syndrome and polycranial neuritis was reported by Gutiérrez-Ortiz et al. [169]. Albumin cytologic dissociation was observed in the CSF after few days of COVID-19 infection in the individuals with Miller Fisher syndrome and polycranial neuritis [169]. Few reports suggested that the demyelination of multiple peripheral nerves might be another reason associated with SARS-CoV-2 that may induce deteriorating conditions of the patients with GBS [170]; however, extensive research studies are required to elucidate this pathophysiology vividly to develop counteracting therapeutic modalities [171].

\section{Encephalomyelitis and SARS-CoV-2}

Acute disseminated encephalomyelitis (ADEM) is one of the reported diseases generated through the central infiltration of SARS-CoV-2 components in the olfactory and trigeminal nerve endings [172]. Patients diagnosed with ADEM associated with SARS-CoV-2 infection suffer from weakness and numbness in the limbs and few urinary disorders; however, to date, the complete pathophysiology is not investigated. The complete CSF analysis in these patients has been reported with xanthochromia with high protein and glucose [172].

\section{Myalgia and Neuromuscular Junction Damage}

Myalgia, referred to as the general muscle pain accompanied by the presence of fatigue, is worsened in SARS-CoV-2 infected individuals due to chronic muscle injury [173]. Myalgic symptoms are due to respiratory complications invoked via acute respiratory distress syndrome (ARDS) and inflammatory-cytokine storm-induced via SARS-CoV-2 pathophysiology through muscle cell ACE-2 receptors [173]. Another evident chronic effect is the immune-mediated muscle damage due to inflammatory cytokine responses in these patients $[174,175]$ (Table 2).

\section{SARS-CoV-2 and Animal Models of Neuronal Damage}

Animal studies on SARS-CoV-2 can deliver key information on the pathophysiology of CNS [159]. For instance, mice, hamsters, ferret, and non-human primate models were already in use to examine the effects of virulence in vivo [176]. Transgenic models of mice expressing the human ACE-2 (hACE-2) gene, which is the receptor for SARSCoV-2 in humans, are one such animal model to study the role of viral infection on neuronal damage.

Potential treatment strategies include pre-treatment with pan-coronavirus fusion inhibitors like EK1 peptide (an amino acid modified OC43-HR2P) and TMPRSS2 inhibitors like Camostat mesylate, Nafamostat mesylate should be tested for the efficacy in these animal models before considering for further assessment. The neural tissues of animal models are beneficial to examine the SARS-CoV-2-induced modulation in ACE-2 [33, 177, 178]. Dysregulation of RAS systems in COVID-19 infection contributes to ischemic brain injury through small-vessel hypoperfusion and arterial atherothrombosis [179]. Molecular mechanisms regulating these processes can be deciphered using mice models of SARS-CoV-2 infection.

Table 2 List of neurological disorders due to SARS-CoV-2 infection

\begin{tabular}{|c|c|c|c|}
\hline Neurological diseases & Disease_clinical manifestations & SARS-CoV-2-induced clinical manifestations & References \\
\hline Parkinson's disease (PD) & Tremors, dyskinesia & $\begin{array}{l}\text { Chronic defects in the mesolimbic system of } \\
\text { basal ganglia mainly in the dopaminergic } \\
\text { neurons; enhanced neurodegeneration }\end{array}$ & {$[148,149]$} \\
\hline Alzheimer's disease (AD) & Cognitive decline and memory loss & $\begin{array}{l}\text { Enhanced accumulation of amyloid-beta } \\
\text { plaques in the brain; enhanced neurodegen- } \\
\text { eration }\end{array}$ & {$[130]$} \\
\hline Multiple sclerosis & Severe lymphopenia, optic neuritis & Extensive demyelination & {$[155]$} \\
\hline Guillain-Barré syndrome (GBS) & $\begin{array}{l}\text { Progressive flaccid paralysis, dyssynergia, } \\
\text { areflexia }\end{array}$ & $\begin{array}{l}\text { Severe autonomic dysfunction, respiratory } \\
\text { failure, demyelination through immune } \\
\text { response in the peripheral nervous system } \\
\text { (PNS) }\end{array}$ & {$[163,165,166]$} \\
\hline Miller Fisher syndrome & Diplopia, balance disturbances, and areflexia & $\begin{array}{l}\text { Chronic demyelination of cranial and facial } \\
\text { nerves }\end{array}$ & [169] \\
\hline $\begin{array}{l}\text { Acute disseminated encephalo- } \\
\text { myelitis (ADEM) }\end{array}$ & $\begin{array}{l}\text { Encephalopathy, transverse myelitis, weak- } \\
\text { ness, numbness of the limbs, and urinary } \\
\text { disorders }\end{array}$ & $\begin{array}{l}\text { Immune-mediated inflammatory demyelina- } \\
\text { tion affecting the white matter of brain and } \\
\text { spinal cord }\end{array}$ & {$[172]$} \\
\hline
\end{tabular}




\section{SARS-CoV and Models for CNS Research}

Accumulating evidence has demonstrated the presence of coronaviruses in the autopsies isolated from CNS of patients suffering from MS, PD, and AD. Experimental studies have shown that human CoVs can easily infect neurons, glial cells viz., astrocytes, and microglia in primary cultures as well as immortalized human microglial cells [180]. This suggests that SARS-CoV-2 may use the brain as a reservoir, which potentially favors the development of neurodegenerative diseases [181]. Therefore, there is a need to analyze the effect of SARS-CoV-2 infection on CNS.

\section{SARS-CoV and CNS Cell Lines}

The existing data, which is available from research on SARS-CoV, showed approximately 78\% nucleotide homology with SARS-CoV-2. However, there are no specific neural cell lines developed to study the models of SARSCoV-2 [182]. Currently neural progenitor cells, neurons, and microglia cells (obtained from human induced pluripotent stem cells (hIPSCs)) are being used to ascertain the in vitro studies of SARS-CoV-2 viral infections and the impact of infection on cellular metabolism and various signaling cascades involved in cellular survival [182-184]. However, few other studies have used neurotropic human coronaviruses and neural cell lines such as human oligodendroglioma cell line HOG and rat glial tumor cell line C6. These cell lines are sensitive to SARS-CoV-2 infection and help to decipher the underlying virulence mechanisms through which the virus attacks the human CNS [185-187]. Even though both cell lines are reported to be sensitive to SARS-CoV infection, it was mentioned that viral replication is very low in cell lines such as Vero E6 and Caco-2 [188]. Miscellaneous neural cell lines viz., "human $\mathrm{H} 4$ brain neuroglioma cells, LA-N-5 human neuroblastoma cells, CHME-5 human fetal microglia cells, and U-373 MG and U-87 MG astrocytic cells" were also used for studying the infection ability of the HCoV-229E and HCoV-OC43 in the CNS [189-193]. Cultures of human primary neurons, glial cells such as astrocytes, oligodendrocytes, and microglia could also be used to study the virulence of the above viruses. Further studies are warranted to test the suitability of these neural cell lines to conduct experiments using SARS-CoV-2.

\section{SARS-CoV-2 and Models of Brain Organoids}

Organoids are the miniaturized, simplified, three-dimensional versions of an organ developed in vitro [194]. Organoids represent the cellular structure and functioning of a particular organ $[195,196]$. The implementation of organoids could foster researchers to develop and ascertain the complex physiological or pathological processes in an in vivo system. SARS-CoV-2 infection, tropism, and potential treatments were examined in human organoids of the lung, liver, intestine, blood vessels, and kidney [196-198]. Currently, human brain organoids are being developed to study the pathophysiological aspects associated with SARSCoV-2-induced alterations in the brain [198, 199]. These organoids are useful to study the early stages of neuronal development during COVID-19 infection.

SARS-CoV-2 infect mature cortical neurons that are present in brain organoids [182]. Besides, the neurodegenerative effects observed in SARS- CoV-2 infected cells are due to cellular death and hyperphosphorylation, followed by the mislocation of Tau protein. These changes were more evident in tauopathies or AD [182]. However, there is no productive viral replication observed in these cells during the initial phase of infection, which would support the hypothesis that the CNS can be considered as a long-term reservoir for the virus [181]. In contrast, Bullen et al. delineated overaccumulation of viral particles across neurons in brain organoid models between 6 and $72 \mathrm{~h}$ after SARS-CoV-2 infection [200]. This is indicating that an active replication was more evident during the initial phase of viral infection. Furthermore, the viral particles were noticed significantly across the neuronal soma as well as in neurites. Mesci et al. [201] have successfully implemented the brain organoid model to assess whether the SARS-CoV-2 could be able to infect neurons, NPCs, and other cortical neurons to foster the cell death accompanied by the failure of excitatory synapses. Also, the above work was examined for Sofosbuvir's efficiency, which is an FDA-approved brain-penetrant antiviral drug for (+) ss RNA viruses, as a part of therapeutic modality during SARS-CoV-2 infection [202]. This study has concluded that Sofosbuvir could reinstate the altered synaptogenesis and mitigate neural cell death induced by viral accumulation in these brain organoids. Another study reported that SARS-CoV-2 exhibits neuro-invasive property in human brain organoids, typically in NPCs and mature cortical neurons [183]. These cells are exemplified by the hypermetabolic state where the viral particles undergo accumulation across the endoplasmic reticulum-like structures. From these evidences, it is now confirmed that SARS-CoV-2 has the capability to utilize neural cell machinery to replicate in the cells. Furthermore, hypoxia, as well as extensive neuronal death, was more evident across the infected brain tissues with high-density SARS-CoV-2, suggesting that SARS-CoV-2 could foster bystander cell death [203]. This study also concluded that $\mathrm{IgG}$ antibodies generated against SARS-CoV-2 in the CSF of COVID-19 patients could confer blockade of SARS-CoV-2 infection in brain organoids [183]. Thus, these studies reported that SARS-CoV-2 could infect neural cells and invoke neurological complications 
with devastating adverse effects. In conclusion results of these studies depicted the immense potential of the usage of human brain organoids for the study of the SARS-CoV-2 effects in the CNS.

\section{MHV-CoV Infection in Mice and Neural Complications}

Mouse hepatitis virus (MHV) is a $\beta \mathrm{CoV}$, which has no risk to humans but typically presents a similarity with other viruses from the same family viz., SARS-CoV, MERS-CoV, and SARS-CoV-2. Furthermore, this virus can cross CNS and invoke white matter lesions; hence this model could be proposed as a viral model of demyelinating disease [204, 205]. MHV can undergo replication in white matter, hence, is a useful model for the study of coronavirus-induced CNS infection. Neurotropic strains of MHV-CoV were previously reported to be implicated to cause acute and chronic demyelinating disease mediated by neuroinflammation [206, 207]. Based on the inoculation route and the MHV-CoV strain, it is now feasible to predict and identify the CNS region that was significantly affected. Inoculation with experimental MHV-A59 neurotropic strains could invoke an acute meningoencephalitis followed by the occurrence of subacute, chronic inflammatory demyelination in both brain and spinal cord [208]. Virus translocation from the initial site of inoculation in the brain to the spinal cord is caused by the transit of virus particles in neural and glial cells and mechanisms that involve the fusion of lipid membranes, probably during the virus internalization step [209]. Intranasal and intracranial inoculation of JHM-CoV induces similar symptoms in BALB/c mice to those caused by MHV-A59. After intranasal inoculation of mice, MHV-CoV accesses the CNS through the olfactory nerve and propagates from the olfactory system to limbic system structures and their connections with the brainstem [210].

In order to study the immune system role in demyelination induction caused by MHV infection, Wang et al. [211] treated infected animals with gamma radiation to cause immunosuppression and, subsequently, reconstituted immunity by transferring cells from other immunocompetent animals. The results concluded that demyelination was prevented by radiation and was reinstated again when the immunity was restored, indicating that immunity is directly involved in the demyelination process. Moreover, CD4 and CD8 T cells have been observed to play a critical role in developing the demyelinating process, with $\mathrm{T}$ cells being the most important for this process [212, 213]; MHV offers a unique model for studying host defense-mediated demyelination during chronic viral infection and acute phase of viral infection (for instance, SARS-CoV-2) [214].

\section{COVID-19 and Impact on Neurodevelopment}

The global COVID-19 pandemic raised concern for pregnant women regarding the outcomes of SARS-CoV-2 infections, as this viral infection may invoke potential fetal defects viz., long-term neurodevelopmental impacts [215].There are three primary considerations for a developing fetus:

Vertical transmission of the disease from the mother The prenatal effects of maternal systemic infection on the fetus

The possible effects on placental functioning and consequent pregnancy outcomes [179]

The presence of ACE-2 receptors in the placenta suggests the potential risk of getting SARS-CoV-2 transmission. In addition to vertical transmission, the maternal infection may invoke neurodevelopmental alterations during fetal development. However, the SARS-CoV-2-induced neurodevelopmental alterations should be unraveled fully to understand the infection-induced pathophysiology in early pregnancy [216]. For instance, this infection could foster the incidence of cytokine storm accompanied by the modulation of maternal immune systems and generate a cascade of cytokines and chemokines (TNF- $\alpha$, IL- 6 ) and other immune alterations that may be transmitted to the fetus. Subsequently, the critically ill pregnant women with viral infection could be at a higher risk of placental hypoxia, compromising fetal oxygen supply

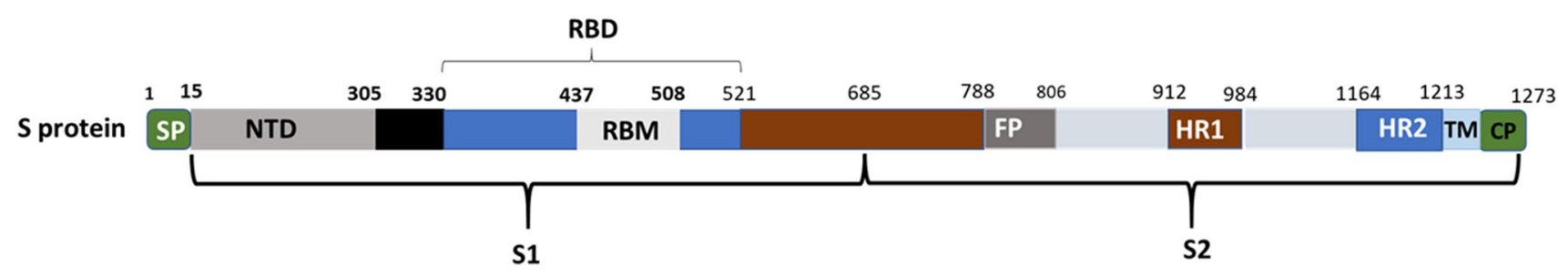

Fig. 5 Structural motifs of S-protein: the S-protein of SARS-CoV-2 is composed of $\mathrm{S} 1$ and $\mathrm{S} 2$ subunits. Whereas the $\mathrm{S} 1$ domain is composed of N-terminal domain (NTD), receptor-binding domain (RBD), receptor-binding motif (RBM), the S2 domain is composed of fusion peptide, heptad repeat 1 (HR1), heptad repeat 2 (HR2), transmembrane domain (TM), and a cytoplasmic domain (CP) 
consequently invoke defects in regional growth and brain development [217-219]. Thus, the impact of COVID-19 on pregnancy remains undetermined in terms of neurological complications in both mother and newborn. Even though reports suggested critical illness and maternal death in few cases, to date, no evidences are reported indicating pregnancy as one of the risk factors for acquiring COVID-19.

\section{Proteins of Virus- and Host-Origin Involved in the Pathogenesis}

\section{S-Protein}

S-protein is one of the viral proteins, which consists of a large ectodomain, a single-pass transmembrane anchor, and a short intracellular tail (Fig. 5) [220]. Ectodomain consists of two subunits: viz., S1 (receptor-binding subunit) and S2 (membrane fusion subunit), serving as primary targets for human inventions. S1 and S2 subunits are highly conserved with $70 \%$ and $99 \%$ similarity with bat SARS-CoV and human SARS-CoV, respectively [1, 221]. S1 functional domains include the $\mathrm{N}$-terminal domain (NTD), receptorbinding domain (RBD), and receptor-binding motif (RBM) (Fig. 5). S2 has a fusion peptide, heptad repeat 1 (HR1), heptad repeat 2 (HR2), transmembrane domain (TM), and a cytoplasmic domain (CP) (Fig. 5) [2, 59, 220]. Electron microscopy studies revealed that the spike appears as a clove-shaped trimer with three S1 heads and a trimeric S2 stalk [222-225]. The receptor-binding subunit interacts efficiently with various host receptors and facilitates the virus attachment on the host cell surface. The membrane fusion subunit fuses the host and viral membrane, mediating the entry of the virus into the host cells [226].

ACE-2 receptor is the binding partner of SARS-CoV2 's S-protein [2, 59]. Studies have reported and confirmed the existence of cross-reaction, by amino-acid sequence analysis of S1 subunit revealing $77 \%$ similarity of SARSCoV-2 to SARS-CoV [29, 227, 228], while S2 subunit of SARS-CoV-2 was highly conserved and shared $99 \%$ homology with human SARS-CoV [1].

The difference in RBD of SARS-CoV and SARS-CoV-2 was that SARS-CoV specific ACE-2 binding neutralizing antibodies (m96, CR3014) failed to bind with the S-protein of SARS-CoV-2 [29]. Analysis of RBD of SARS-CoV and SARS-CoV-2 showed the presence of arginine (R426) in SARS-CoV RBD compared to asparagine (N439) in SARS$\mathrm{CoV}-2$, which leads to a significant decrease in the strong polar interactions [229]. Similarly, a replacement of valine (V404 in SARS-CoV) by lysine (K417 in SARS-CoV-2) on

Table 3 List of US-FDA approved vaccines under clinical trials

\begin{tabular}{|c|c|c|c|c|c|c|}
\hline Vaccine name & Type of vaccine & $\begin{array}{l}\text { Current stage of } \\
\text { the clinical trial }\end{array}$ & Efficacy & Dosing regimen & $\begin{array}{l}\text { Type of administra- } \\
\text { tion }\end{array}$ & $\begin{array}{l}\text { Manufacturer of the } \\
\text { vaccine }\end{array}$ \\
\hline $\begin{array}{l}\text { Comirnaty/tozinam- } \\
\text { eran/BNT162b2 }\end{array}$ & mRNA vaccine & Phases 2, 3 & $95 \%$ & $\begin{array}{l}2 \text { doses, } 3 \text { weeks } \\
\text { apart }\end{array}$ & Muscle injection & Pfizer and BioNTech \\
\hline mRNA-1273 & mRNA vaccine & Phase 3 & $94.5 \%$ & $\begin{array}{l}2 \text { doses, } 4 \text { weeks } \\
\text { apart }\end{array}$ & Muscle injection & Moderna \\
\hline $\begin{array}{l}\text { Sputnik V/Gam- } \\
\text { Covid-Vac }\end{array}$ & $\begin{array}{l}\text { Viral vector (Ad26, } \\
\text { Ad5) }\end{array}$ & Phase 3 & $91.6 \%$ & $\begin{array}{l}2 \text { doses, } 3 \text { weeks } \\
\text { apart }\end{array}$ & Muscle injection & $\begin{array}{l}\text { Gamaleya Research } \\
\text { Institute }\end{array}$ \\
\hline $\begin{array}{l}\text { AZD1222/Cov- } \\
\text { ishield }\end{array}$ & $\begin{array}{l}\text { Viral vector } \\
\quad(\text { ChAd } 0 \times 1)\end{array}$ & Phases 2, 3 & $82.4 \%$ & 2 doses & Muscle injection & $\begin{array}{l}\text { University of Oxford } \\
\text { and AstraZeneca }\end{array}$ \\
\hline $\begin{array}{l}\text { Convidecia/Ad5- } \\
\text { nCoV }\end{array}$ & Viral vector (Ad5) & Phase 3 & Unknown & Single dose & Muscle injection & CanSino Biologics \\
\hline EpiVacCorona & Protein subunit & Phase 3 & Unknown & $\begin{array}{l}2 \text { doses, } 3 \text { weeks } \\
\text { apart }\end{array}$ & Muscle injection & Vector Institute \\
\hline BBIBP-CorV & Inactivated & Phase 3 & $79.34 \%$ & $\begin{array}{l}2 \text { doses, } 3 \text { weeks } \\
\text { apart }\end{array}$ & Muscle injection & $\begin{array}{l}\text { Sinopharm and Beijing } \\
\text { Institute of Biologi- } \\
\text { cal Products }\end{array}$ \\
\hline CoronaVac & Inactivated & Phase 3 & $50.38 \%$ & $\begin{array}{l}2 \text { doses, } 2 \text { weeks } \\
\text { apart }\end{array}$ & Muscle injection & Sinovac Biotech \\
\hline Covaxin & Inactivated & Phase 3 & Unknown & $\begin{array}{l}2 \text { doses, } 4 \text { weeks } \\
\text { apart }\end{array}$ & Unknown & $\begin{array}{l}\text { Indian Council of } \\
\text { Medical Research, } \\
\text { National Institute of } \\
\text { Virology and Bharat } \\
\text { Biotech }\end{array}$ \\
\hline Name not announced & Inactivated & Phase 3 & Unknown & Unknown & Unknown & $\begin{array}{l}\text { Sinopharm and Wuhan } \\
\text { Institute of Biologi- } \\
\text { cal Products }\end{array}$ \\
\hline
\end{tabular}


$\beta 6$ formed an extra salt bridge with D30 on ACE-2 [228]. The structural changes in the RBM modulate the hACE2-binding ridge into a more compact one, which facilitates better interaction with $\mathrm{N}$-terminal hACE-2, making SARSCoV-2 a more favorable binding partner [230] (Fig. 5).

\section{TMPRSS2}

TMPRSS2 is a cellular serine protease, which [57, 231, 232] plays a significant role in the entry of coronaviruses such as SARS-CoV and MERS-CoV into host cells [233, 234]. Several investigators have confirmed that TMPRSS2 causes S-protein priming for SARS-CoV-2 entry into primary target cells and enables the spreading of the virus in the infected host $[33,56,235,236]$. Thus, TMPRSS 2 is an attractive drug target for blocking the initial step of SARS-CoV-2 infection to avoid multiorgan dysfunction. However, the above intricate structure of S-protein interaction with TMPRSS2 is a challenging aspect for virologists to develop suitable therapeutic interventions against SARS-CoV-2.

\section{Targeting COVID-19 Using Vaccines}

As of 3 April 2021, 83 vaccine candidates are currently in clinical trials on humans and 77 vaccine candidates are under investigation in animals. Among which 48 are in phase I, 33 in phase II, and 23 in phase III evaluation (Table 3, Fig. 6). Some of the vaccine candidates are currently in phase III clinical trials and the clinical data is supportive of large-scale manufacturing in several industrial production units worldwide with complete FDA approval [237].

The current COVID-19 vaccine candidates are antibody and/or $\mathrm{T}$ cell immune response promoting agents [237]. For instance, the protein-based vaccines are safe and induce immune responses through the adjuvants used along with the vaccine. Mainly, the S-protein, which is composed of S1 RBD, RBD$\mathrm{Fc}$, and $\mathrm{N}$-terminal regions, could exert immune protection in several in vivo and nonhuman primate models [238-242]. Furthermore, the subunit vaccines could invoke immune responses in the host through one or more antigens in the presence of a suitable adjuvant. However, the immunization through subunit vaccine in animal models is capable of inducing fusion of S1 RBD with IgG1 FC portion consequently actuate generation of highly potent antibodies to foster neutralization of SARS-CoV [243, 244]. The clinical models of SARS-CoV-2 are yet to be examined for subunit vaccine as there is a very minimal success with clinical efficacy in animal models.

\section{Ozonation of Vaccine}

Systemic ozone therapy (OT) could be referred to as the potential approach useful in SARS-CoV-2 [245]. OT can be beneficial for the effective clinical management of complications secondary to SARS-CoV-2 [245]. OT improves oxygenation and exerts protection against lung fibrosis [246] and renal failure [247]. Furthermore, this therapy can stabilize the plasma levels in viral-infected patients by improving hepatic protein synthesis [248]. It could also exert a cytoprotective effect by preventing oxidative damage to the heart [249, 250], liver [251, 252], and renal tissues [253]. Systemic OT has the capacity to modulate the expression of the NF- $\kappa \mathrm{B} / \mathrm{Nrf} 2$ pathway and IL-6/IL-1 $\beta$ pathway consequently foster cytoprotection by blocking viral replication [245]. Previously, hormetic responses and oxidative preconditioning have been examined experimentally to the chronic oxidative stress during OT [254]. However, the hormetic responses of ozone were delineated vividly. For instance, a high dose of ozone can modulate gene transcription of proinflammatory cytokines and inflammatory cytokines while inducing a negative regulation of type 1 IFN in response to viral infection pathways [255]. Despite OT has no significant effect to kill the virus but it has the ability to modulate oxidative stress and inflammatory cytokines; hence OT could be considered as a complementary proposed treatment in COVID-19 patients. Exemplarily, the global vaccine preparation against HIV involves the prolonged and controlled exposure of plasma to a "precise dose of ozone" [245]. Similarly, therapeutic human albumin and ozonated ethyl oleate are predominantly mixed to enhance the absorption and boost the immune function through the vaccine [248, 256, 257]. This kind of ozonation of the vaccine approach towards the preparation of the COVID-19 vaccine can enhance the "oxidation of free viral components" thereby improves the efficacy.

\section{Viral Vector-Based Vaccines.}

These vaccines could promote the delivery of one or more antigens coded through a modified viral vector [258]. This technology promotes the delivery of antigens into the host cells and fosters the generation of both humoral and cellbased immune responses against viral pathogen [244, 259, 260]. The efficacy of viral vectors is yet to be examined against SARS-CoV and SARS- CoV-2. Previous reports delineated the efficacy of the modified vaccinia Ankara (MVA) vector, a live attenuated vector-based vaccine that encodes S-protein [261]. It induces a potent neutralizing antibody in mice, rabbits, and monkeys [262]. Immunization of mice models using recombinant adenovirus has been shown to induce neutralizing antibodies in serum and CD8 + T cells of lungs [263-266].

DNA vaccines consist of plasmid DNA molecules, which encode for immunogens and proven to be more effective than mRNA vaccines for stability and easy delivery [267]. However, their implications are constrained by the risk of 
Fig. 6 List of vaccines in various stages of clinical trials: current SARS-CoV-2 vaccine candidates targeting various biomolecules of the virus. Viral biomolecules targeting vaccine candidates include DNA-based vaccines, inactivated virus, live attenuated virus, non-replicating viral vector, protein subunit, replicating viral vector, RNAbased, and virus-like particlebased vaccines

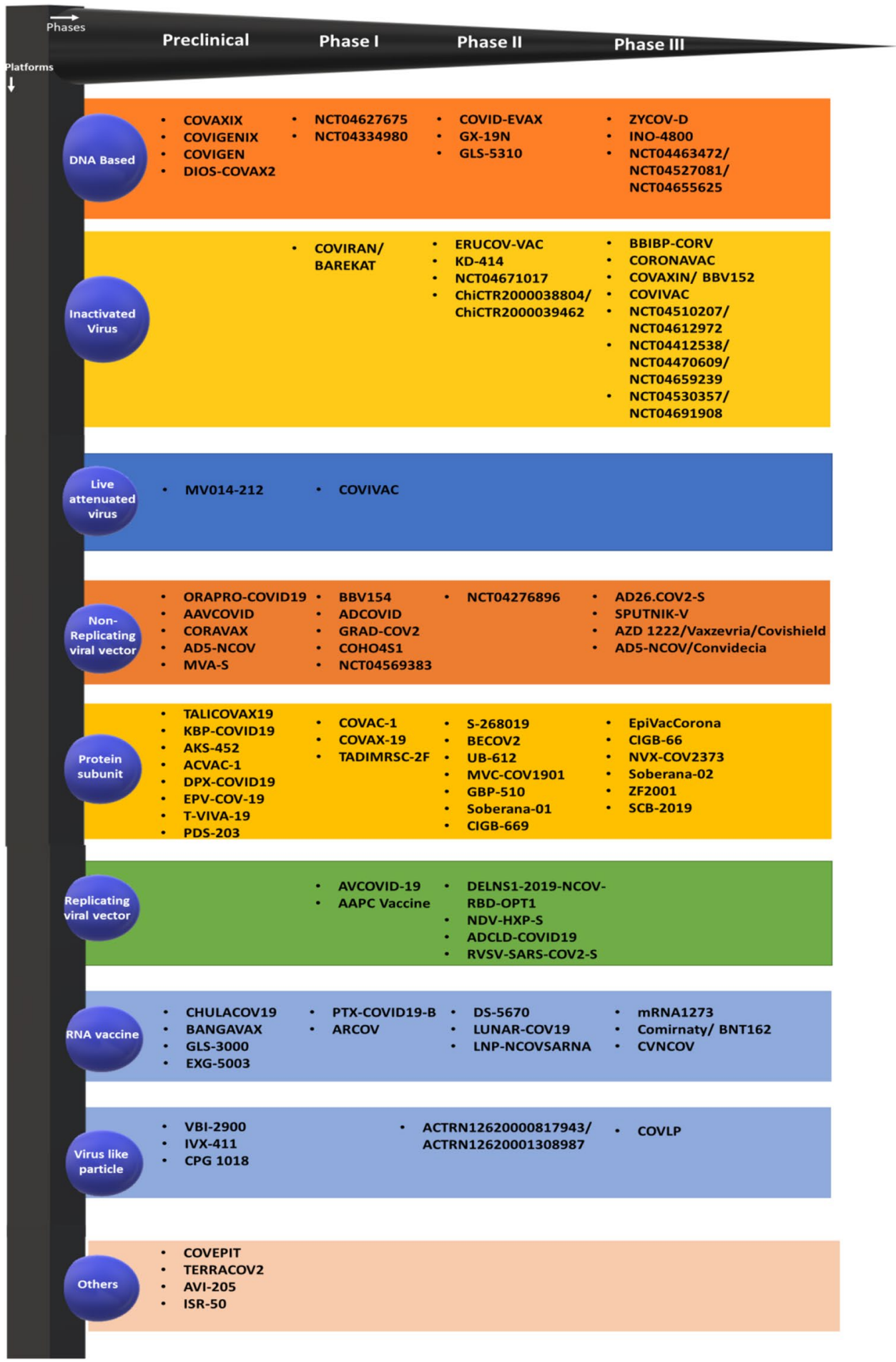

getting mutations by integrating with the host genome [267, 268]. The passive transfer of sera from immunized mice with DNA that encodes the S-domain of MERS-CoV has been shown to protect naïve mice infected with MERS-CoV [269]. Another study showed that DNA encoding S1 and S-proteins invoke the generation of cross-neutralizing antibodies towards multiple MERS-CoV strains originated from humans and camels [270]. Furthermore, the immunization of mice with S-protein encoding DNA has been conducive to the generation of CD4 + and CD8 + T cells specific peptides, which consequently enhanced the extensive cytokine expression [271]. In the case of pseudotyped lentiviral vector-based DNA, the vaccine-induced potent neutralizing antibodies in SARS-CoV consequently invoked S-protein-specific 
$\mathrm{CD} 4+$ and $\mathrm{CD} 8+\mathrm{T}$ cell immune responses in immunized volunteers [272]. A summary of the ongoing DNA/subunit/ protein-based vaccine trials are provided in Table 2 . However, the implications of these vaccine models in SARSCoV-2 are constrained by the antibody-dependent enhancement (ADEs) and Th2-immunopathology.

\section{Successful Phase II COVAXIN (Bharat Biotech)}

BBV152 (COVAXIN) is a whole-virion $\beta$-propiolactoneinactivated SARS-CoV-2 vaccine investigated and formulated along with a toll-like receptor $7 / 8$ agonist (imidazoquinoline molecule) to foster Th-1 immune responses through the intramuscular route of administration [273, 274]. A double-blind, multicenter, and randomized controlled phase I trial was conducted across 11 hospitals in India by Bharat Biotech. Further, this study assessed the safety and immunogenicity of BBV152 (Clinical Trials.gov NCT04471519) assessment of safety and immunogenicity of BBV152 [275]. However, additional studies are required to ascertain the cell-mediated responses.

Covishield is another vaccine developed by Serum Institute of India (SII) in collaboration with Oxford-AstraZeneca, UK, and Bharat Biotech. This vaccine was approved by the Drugs Controller General of India (DCGI) recently for emergency usage through the intramuscular route of administration in SARS-CoV-2 infected patients in India (DCGI, India).

\section{Vaccine-Induced Neurological Complications}

To date, 665 million vaccine doses have been administered worldwide. Several recent reports suggest that the COVID19 vaccination has no- or minimal risk to the neurological system $[171,276]$. However, mild side effects such as dizziness, headache, pain, muscle spasms, myalgia, and paresthesias were reported in the clinical trials of the vaccines during phase III study [276]. For instance, AZD1222 adenoviral vector vaccine administration during phase III trial in two patients was reported with neurological complications. Upon detailed investigation, it was concluded that one patient exhibited multiple sclerosis, which was undiagnosed at the time of vaccination, and the later reports concluded that the other factors might be contributing to this side effect [277-279]. Subsequently, these reports delineated that this vaccine had no neurological side effects and the study was resumed, with approvals in India, Argentina, and the UK [277]. In an mRNA vaccine trial, 7 out of 37,000 participants developed Bell's palsy (a temporary weakness or paralysis of the muscles in the face); US-FDA concluded that the rate of the disease was not higher than expected in the population [280]. A vaccine candidate developed by Johnson \& Johnson has been reported with GBS in two patients in the phase III trial. Among them, one participant was vaccinated and the other was a placebo, suggesting that there was no association between GBS and COVID-19 infection [281]. A case study by Waheed et al. reported the first case of GBS after 2 weeks of the first dose of Pfizer COVID-19 vaccine (mRNA vaccine) [171]. In rare case, the vaccine administration that was associated with tremor, diplopia (simultaneous perception of two images of a single object), tinnitus (experience of ringing or other noises in one or both the ears), dysphonia (abnormal voice), seizures, and reactivation of herpes zoster has been reported [276]. To date, 17 cases of stroke, 32 cases of GBS, 190 cases of Bell's palsy, and 6 cases of encephalomyelitis have been reported in the "Vaccine Adverse Event Reporting System database" [276]. However, there is no significant report that suggests a higher rate of neurological complications with COVID-19 vaccination [276].

\section{Conclusions}

Infection with SARS-CoV-2, the culprit for the COVID-19 pandemic, has caused several health complications, including the disturbances associated with the neurological system and cognition-related behavioral changes. Fundamental molecular mechanisms that triggered these alterations are reported to be inflammation, induction of cell death, and poor cell-to-cell communications. However, further studies are warranted to address and further confirm (a) whether SARS-CoV-2 can directly enter the neuronal cells? If so, what is the route of entry? (b) The pathogenic responses triggered in infected cells? (c) Why only certain COVID-19 patients develop neurological complications? Moreover, (d) is there any association between age group and susceptibility to COVID-19 induced neurological damage? Further, it is also unknown whether the vaccines that the FDA approves could also extend protection to prevent the entry of SARS-CoV-2 into neuronal cells. Addressing these queries would likely provide clues and mechanisms that can be considered for developing better treatment agents and protection strategies from SARS-CoV-2 infections.

Acknowledgements Dr. Gjumrakch Aliev (GA) would like to thank the GALLY International Research Institute, San Antonio, TX, USA. Prof. Aliev passed away in the month of December 2020. Chinnappa A. Uthaiah (CAU) would like to thank the Department of Science and Technology-Cognition Science Research Initiative (DST-CSRI), Govt of India for providing a Senior Research Fellowship as a part of research grant (No. SR/CSRI/44/2016); Suma M. Nataraj (SMN) would like to thank the Indian Council of Medical Research, Govt of India for sanctioning a research project (No. 54/06/2019-HUM/BMS); and SubbaRao V. Madhunapantula (SVM) thank the research grant award by the Department of Biotechnology, Govt of India (No. BT/PR29598/ PFN/20/1392/2018). SVM would also like to thank the Special Interest Group in Cancer Biology and Cancer Stem Cells (SIG-CBCSC), JSS Academy of Higher Education \& Research (JSS AHER), Mysore 570015, Karnataka, India. 
Author Contribution Medha Karnik (MK), Narasimha M. Beeraka (NMB), Chinnappa A. Uthaiah (CAU), SubbaRao V. Madhunapantula (SVM), Suma M. Nataraj (SMN), Anjali Devi S. Bettadapura (ASB), and Gjumrakch Aliev (GA) conceptualized and designed the study. MK and NMB contributed equally to this work. MK, NMB, and CAU performed the literature analysis and wrote the original manuscript draft. MK, NMB, and SVM revised and improved the final draft. All authors have reviewed and approved the manuscript before submission.

Data availability Not applicable.

\section{Declarations}

Ethics Approval Not applicable.

Consent to Participate Not applicable.

Consent for Publication All authors have reviewed and approved the manuscript before submission.

Conflict of Interest The authors declare no competing interests.

\section{References}

1. Chan JF-W, Kok K-H, Zhu Z, Chu H, To KK-W, Yuan S, Yuen K-Y (2020) Genomic characterization of the 2019 novel humanpathogenic coronavirus isolated from a patient with atypical pneumonia after visiting Wuhan. Emerging microbes \& infections 9(1):221-236

2. Lu R, Zhao X, Li J, Niu P, Yang B, Wu H, Wang W, Song H, Huang B, Zhu N (2020) Genomic characterisation and epidemiology of 2019 novel coronavirus: implications for virus origins and receptor binding. The Lancet 395(10224):565-574

3. Wang Q, Zhang Y, Wu L, Niu S, Song C, Zhang Z, Lu G, Qiao C, $\mathrm{Hu}$ Y, Yuen K-Y (2020) Structural and functional basis of SARSCoV-2 entry by using human ACE2. Cell 181(4):894-904.e899

4. Tyrrell D, Bynoe M (1965) Cultivation of a novel type of common-cold virus in organ cultures. BMJ 1(5448): 1467

5. Lechien JR, Chiesa-Estomba CM, De Siati DR, Horoi M, Le Bon SD, Rodriguez A, Dequanter D, Blecic S, El Afia F, Distinguin L (2020) Olfactory and gustatory dysfunctions as a clinical presentation of mild-to-moderate forms of the coronavirus disease (COVID-19): a multicenter European study. Eur Arch Otorhinolaryngol 277(8):2251-2261

6. Guan W-j, Ni Z-y, Hu Y, Liang W-h, Ou C-q, He J-x, Liu L, Shan H, Lei C-1, Hui DS (2020) Clinical characteristics of coronavirus disease 2019 in China. N Engl J Med 382(18):1708-1720

7. Cui J, Li F, Shi Z-L (2019) Origin and evolution of pathogenic coronaviruses. Nat Rev Microbiol 17(3):181-192

8. Chen Y, Liu Q, Guo D (2020) Emerging coronaviruses: genome structure, replication, and pathogenesis. J Med Virol 92(4):418-423

9. Ong SWX, Tan YK, Chia PY, Lee TH, Ng OT, Wong MSY, Marimuthu K (2020) Air, surface environmental, and personal protective equipment contamination by severe acute respiratory syndrome coronavirus 2 (SARS-CoV-2) from a symptomatic patient. JAMA 323(16):1610-1612

10. Gordon DE, Jang GM, Bouhaddou M, Xu J, Obernier K, White KM, O’Meara MJ, Rezelj VV, Guo JZ, Swaney DL (2020) A SARS-CoV-2 protein interaction map reveals targets for drug repurposing. Nature 583(7816):459-468
11. Hussain S, Chen Y, Yang Y, Xu J, Peng Y, Wu Y, Li Z, Zhu Y, Tien P, Guo D (2005) Identification of novel subgenomic RNAs and noncanonical transcription initiation signals of severe acute respiratory syndrome coronavirus. J Virol 79(9):5288-5295

12. Snijder EJ, Van Der Meer Y, Zevenhoven-Dobbe J, Onderwater JJ, Van Der Meulen J, Koerten HK, Mommaas AM (2006) Ultrastructure and origin of membrane vesicles associated with the severe acute respiratory syndrome coronavirus replication complex. J Virol 80(12):5927-5940

13. Demogines A, Farzan M, Sawyer SL (2012) Evidence for ACE2utilizing coronaviruses $(\mathrm{CoVs})$ related to severe acute respiratory syndrome CoV in bats. J Virol 86(11):6350-6353

14. Neuman BW, Kiss G, Kunding AH, Bhella D, Baksh MF, Connelly S, Droese B, Klaus JP, Makino S, Sawicki SG (2011) A structural analysis of $\mathrm{M}$ protein in coronavirus assembly and morphology. J Struct Biol 174(1):11-22

15. DeDiego ML, Álvarez E, Almazán F, Rejas MT, Lamirande E, Roberts A, Shieh W-J, Zaki SR, Subbarao K, Enjuanes L (2007) A severe acute respiratory syndrome coronavirus that lacks the $\mathrm{E}$ gene is attenuated in vitro and in vivo. J Virol 81(4):1701-1713

16. Fehr A, HJ PSM, Bickerton E, Britton P (2015) An overview of their replication and pathogenesis; section 2 genomic organization. Methods in molecular biology. Springer 1282:1-23

17. Cui L, Wang H, Ji Y, Yang J, Xu S, Huang X, Wang Z, Qin L, Tien P, Zhou X (2015) The nucleocapsid protein of coronaviruses acts as a viral suppressor of RNA silencing in mammalian cells. J Virol 89(17):9029-9043

18. Angeletti S, Benvenuto D, Bianchi M, Giovanetti M, Pascarella S, Ciccozzi M (2020) COVID-2019: the role of the nsp2 and nsp3 in its pathogenesis. J Med Virol 92(6):584-588

19. Beeraka NM, Sadhu SP, Madhunapantula SV, Rao Pragada R, Svistunov AA, Nikolenko VN, Mikhaleva LM, Aliev G (2020) Strategies for targeting SARS CoV-2: small molecule inhibitors-the current status. Front Immunol 11 (2264). https://doi. org/10.3389/fimmu.2020.552925

20. Yang D, Tong L, Wang D, Wang Y, Wang X, Bai C (2010) Roles of CC chemokine receptors (CCRs) on lipopolysaccharide-induced acute lung injury. Respir Physiol Neurobiol 170(3):253-259

21. Bottemanne P, Paquot A, Ameraoui H, Alhouayek M, Muccioli GG (2019) The $\alpha / \beta$-hydrolase domain 6 inhibitor WWL70 decreases endotoxin-induced lung inflammation in mice, potential contribution of 2-arachidonoylglycerol, and lysoglycerophospholipids. FASEB J 33(6):7635-7646

22. Chakraborty A, Koldobskiy MA, Bello NT, Maxwell M, Potter JJ, Juluri KR, Maag D, Kim S, Huang AS, Dailey MJ (2010) Inositol pyrophosphates inhibit Akt signaling, thereby regulating insulin sensitivity and weight gain. Cell 143(6):897-910

23. Kindrachuk J, Ork B, Hart BJ, Mazur S, Holbrook MR, Frieman MB, Traynor D, Johnson RF, Dyall J, Kuhn JH (2015) Antiviral potential of ERK/MAPK and PI3K/AKT/mTOR signaling modulation for Middle East respiratory syndrome coronavirus infection as identified by temporal kinome analysis. Antimicrob Agents Chemother 59(2):1088-1099

24. Sisk JM, Frieman MB, Machamer CE (2018) Coronavirus S protein-induced fusion is blocked prior to hemifusion by $\mathrm{Abl}$ kinase inhibitors. J Gen Virol 99(5):619

25. Cheng H, Lear-Rooney CM, Johansen L, Varhegyi E, Chen ZW, Olinger GG, Rong L (2015) Inhibition of Ebola and Marburg virus entry by $\mathrm{G}$ protein-coupled receptor antagonists. J Virol 89(19):9932-9938

26. Fatma B, Kumar R, Singh VA, Nehul S, Sharma R, Kesari P, Kuhn RJ, Tomar S (2020) Alphavirus capsid protease inhibitors 
as potential antiviral agents for Chikungunya infection. Antiviral Res 179:104808

27. Wang C, Li W, Drabek D, Okba NM, van Haperen R, Osterhaus AD, van Kuppeveld FJ, Haagmans BL, Grosveld F, Bosch B-J (2020) A human monoclonal antibody blocking SARS-CoV-2 infection. Nat Commun 11(1):1-6

28. Monteil V, Kwon H, Prado P, Hagelkrüys A, Wimmer RA, Stahl M, Leopoldi A, Garreta E, Del Pozo CH, Prosper F (2020) Inhibition of SARS-CoV-2 infections in engineered human tissues using clinical-grade soluble human ACE2. Cell 181(4):905-913. e907

29. Yuan M, Wu NC, Zhu X, Lee C-CD, So RT, Lv H, Mok CK, Wilson IA (2020) A highly conserved cryptic epitope in the receptor binding domains of SARS-CoV-2 and SARS-CoV. Science 368(6491):630-633

30. Zumla A, Chan JF, Azhar EI, Hui DS, Yuen K-Y (2016) Coronaviruses-drug discovery and therapeutic options. Nat Rev Drug Discovery 15(5):327-347

31. Sawicki SG, Sawicki DL, Siddell SG (2007) A contemporary view of coronavirus transcription. J Virol 81(1):20-29

32. Xia S, Liu M, Wang C, Xu W, Lan Q, Feng S, Qi F, Bao L, Du L, Liu S (2020) Inhibition of SARS-CoV-2 (previously 2019-nCoV) infection by a highly potent pan-coronavirus fusion inhibitor targeting its spike protein that harbors a high capacity to mediate membrane fusion. Cell Res 30(4):343-355

33. Hoffmann M, Kleine-Weber H, Schroeder S, Krüger N, Herrler T, Erichsen S, Schiergens TS, Herrler G, Wu N-H, Nitsche A (2020) SARS-CoV-2 cell entry depends on ACE2 and TMPRSS2 and is blocked by a clinically proven protease inhibitor. Cell 181(2):271-280.e278

34. Sanders JM, Monogue ML, Jodlowski TZ, Cutrell JB (2020) Pharmacologic treatments for coronavirus disease 2019 (COVID19): a review. JAMA 323(18):1824-1836

35. Bittmann S, Luchter E, Weissenstein A, Villalon G, MoschuringAlieva E (2020) TMPRSS2-inhibitors play a role in cell entry mechanism of COVID-19: an insight into camostat and nefamostat. J Regen Biol Med 2(2):1-3

36. Sonawane K, Barale SS, Dhanavade MJ, Waghmare SR, Nadaf $\mathrm{NH}$, Kamble SA, Mohammed AA, Makandar AM, Fandilolu PM, Dound AS (2020) Homology modeling and docking studiesof TMPRSS2 with experimentally known inhibitors camostatmesylate, nafamostat and bromhexine hydrochloride to controlSARS-coronavirus-2. ChemRxiv. https://doi.org/10.26434/chemr xiv.12162360.v1

37. Jankun J (2020) COVID-19 pandemic; transmembrane protease serine 2 (TMPRSS2) inhibitors as potential drugs. Translation $7: 1-5$

38. Wang M, Cao R, Zhang L, Yang X, Liu J, Xu M, Shi Z, Hu Z, Zhong W, Xiao G (2020) Remdesivir and chloroquine effectively inhibit the recently emerged novel coronavirus (2019-nCoV) in vitro. Cell Res 30(3):269-271

39. Tipnis SR, Hooper NM, Hyde R, Karran E, Christie G, Turner AJ (2000) A human homolog of angiotensin-converting enzyme. Cloning and functional expression as a captopril-insensitive carboxypeptidase. J Biol Chem 275(43):33238-33243. https://doi. org/10.1074/jbc.M002615200

40. Warner FJ, Lew RA, Smith AI, Lambert DW, Hooper NM, Turner AJ (2005) Angiotensin-converting enzyme 2 (ACE2), but not ACE, is preferentially localized to the apical surface of polarized kidney cells. J Biol Chem 280(47):39353-39362

41. Hamming I, Timens W, Bulthuis M, Lely A, Gv Navis, van Goor $\mathrm{H}$ (2004) Tissue distribution of ACE2 protein, the functional receptor for SARS coronavirus. A first step in understanding SARS pathogenesis. J Pathol 203(2):631-637

42. Paizis G, Tikellis C, Cooper ME, Schembri JM, Lew RA, Smith AI, Shaw T, Warner FJ, Zuilli A, Burrell LM (2005) Chronic liver injury in rats and humans upregulates the novel enzyme angiotensin converting enzyme 2. Gut 54(12):1790-1796

43. Doobay MF, Talman LS, Obr TD, Tian X, Davisson RL, Lazartigues E (2007) Differential expression of neuronal ACE2 in transgenic mice with overexpression of the brain reninangiotensin system. Am J Physiol Regul Integr Comp Physiol 292(1):R373-R381

44. Hartupee J, Mann DL (2017) Neurohormonal activation in heart failure with reduced ejection fraction. Nat Rev Cardiol 14(1):30-38

45. Hofmann H, Pyrc K, Van Der Hoek L, Geier M, Berkhout B, Pöhlmann S (2005) Human coronavirus NL63 employs the severe acute respiratory syndrome coronavirus receptor for cellular entry. Proc Natl Acad Sci 102(22):7988-7993

46. Li W, Moore MJ, Vasilieva N, Sui J, Wong SK, Berne MA, Somasundaran M, Sullivan JL, Luzuriaga K, Greenough TC (2003) Angiotensin-converting enzyme 2 is a functional receptor for the SARS coronavirus. Nature 426(6965):450-454

47. Gralinski LE, Menachery VD (2020) Return of the coronavirus: 2019-nCoV. Viruses 12(2):135

48. Xu X, Chen P, Wang J, Feng J, Zhou H, Li X, Zhong W, Hao $P(2020)$ Evolution of the novel coronavirus from the ongoing Wuhan outbreak and modeling of its spike protein for risk of human transmission. Sci China Life Sci 63(3):457-460

49. Donoghue M, Hsieh F, Baronas E, Godbout K, Gosselin M, Stagliano N, Donovan M, Woolf B, Robison K, Jeyaseelan R (2000) A novel angiotensin-converting enzyme-related carboxypeptidase (ACE2) converts angiotensin I to angiotensin 1-9. Circ Res 87(5):e1-e9

50. Zhang H, Wada J, Hida K, Tsuchiyama Y, Hiragushi K, Shikata K, Wang H, Lin S, Kanwar YS, Makino H (2001) Collectrin, a collecting duct-specific transmembrane glycoprotein, is a novel homolog of ACE2 and is developmentally regulated in embryonic kidneys. J Biol Chem 276(20):17132-17139

51. Harding S, Vescovo G, Kirby M, Jones S, Gurden J, PooleWilson P (1988) Contractile responses of isolated adult rat and rabbit cardiac myocytes to isoproterenol and calcium. J Mol Cell Cardiol 20(7):635-647

52. Imai Y, Kuba K, Rao S, Huan Y, Guo F, Guan B, Yang P, Sarao R, Wada T, Leong-Poi H (2005) Angiotensin-converting enzyme 2 protects from severe acute lung failure. Nature 436(7047):112-116

53. Kuba K, Imai Y, Rao S, Gao H, Guo F, Guan B, Huan Y, Yang P, Zhang Y, Deng W (2005) A crucial role of angiotensin converting enzyme 2 (ACE2) in SARS coronavirus-induced lung injury. Nat Med 11(8):875-879

54. Simmons G, Zmora P, Gierer S, Heurich A, Pöhlmann S (2013) Proteolytic activation of the SARS-coronavirus spike protein: cutting enzymes at the cutting edge of antiviral research. Antiviral Res 100(3):605-614

55. Wrapp D, Wang N, Corbett KS, Goldsmith JA, Hsieh C-L, Abiona O, Graham BS, McLellan JS (2020) Cryo-EM structure of the 2019-nCoV spike in the prefusion conformation. Science 367(6483):1260-1263

56. Iwata-Yoshikawa N, Okamura T, Shimizu Y, Hasegawa H, Takeda M, Nagata N (2019) TMPRSS2 contributes to virus spread and immunopathology in - coronavirus infection. J Virol 93(6):e01815-18. https://doi.org/10.1128/JVI.01815-18

57. Matsuyama S, Nagata N, Shirato K, Kawase M, Takeda M, Taguchi F (2010) Efficient activation of the severe acute respiratory syndrome coronavirus spike protein by the transmembrane protease TMPRSS2. J Virol 84(24):12658-12664

58. Belouzard S, Chu VC, Whittaker GR (2009) Activation of the SARS coronavirus spike protein via sequential proteolytic cleavage at two distinct sites. Proc Natl Acad Sci 106(14):5871-5876 
59. Wan Y, Shang J, Graham R, Baric RS, Li F (2020) Receptor recognition by the novel coronavirus from Wuhan: an analysis based on decade-long structural studies of SARS coronavirus. J Virol 94(7):e00127-20

60. Bosch BJ, Van der Zee R, De Haan CA, Rottier PJ (2003) The coronavirus spike protein is a class I virus fusion protein: structural and functional characterization of the fusion core complex. J Virol 77(16):8801-8811

61. Fehr AR, Perlman S (2015) Coronaviruses: an overview of their replication and pathogenesis. Methods in Molecular Biology (Clifton, N.J.) 1282:1-23. https://doi.org/10.1007/ 978-1-4939-2438-7_1

62. Severe Covid-19 GWAS Group, Ellinghaus D, Degenhardt F, Bujanda L, Buti M, Albillos A, Invernizzi P, Fernández J, Prati D, Baselli G, Asselta R, Grimsrud MM, Milani C, Aziz F, Kässens J, May S, Wendorff M, Wienbrandt L, Uellendahl-Werth F, Zheng T, ... Karlsen TH (2020) Genomewide association study of severe Covid-19 with respiratory failure. The New England Journal of Medicine 383(16):1522-1534 https://doi. org/10.1056/NEJMoa2020283

63. Rigat B, Hubert C, Alhenc-Gelas F, Cambien F, Corvol P, Soubrier F (1990) An insertion/deletion polymorphism in the angiotensin I-converting enzyme gene accounting for half the variance of serum enzyme levels. J Clin Investig 86(4):1343-1346

64. Baig AM, Khaleeq A, Ali U, Syeda H (2020) Evidence of the COVID-19 virus targeting the CNS: tissue distribution, hostvirus interaction, and proposed neurotropic mechanisms. ACS Chem Neurosci 11(7):995-998

65. Xu Z, Shi L, Wang Y, Zhang J, Huang L, Zhang C, Liu S, Zhao P, Liu H, Zhu L (2020) Pathological findings of COVID-19 associated with acute respiratory distress syndrome. Lancet Respir Med 8(4):420-422

66. Yang X, Yu Y, Xu J, Shu H, Liu H, Wu Y, Zhang L, Yu Z, Fang M, Yu T (2020) Clinical course and outcomes of critically ill patients with SARS-CoV-2 pneumonia in Wuhan, China: a single-centered, retrospective, observational study. Lancet Respir Med 8(5):475-481

67. Chai X, Hu L, Zhang Y, Han W, Lu Z, Ke A, Zhou J, Shi G, Fang N, Fan J (2020) Specific ACE2 expression in cholangiocytes may cause liver damage after 2019-nCoV infection. Biorxiv. https:// doi.org/10.1101/2020.02.03.931766

68. Fan Z, Chen L, Li J, Cheng X, Yang J, Tian C, Zhang Y, Huang S, Liu Z, Cheng J (2020) Clinical features of COVID-19-related liver functional abnormality. Clin Gastroenterol Hepatol 18(7):1561-1566

69. Fan C, Lu W, Li K, Ding Y, Wang J (2021) ACE2 expression in kidney and testis may cause kidney and testis infection in COVID-19 patients. Front Med 7:1045

70. Oudit G, Kassiri Z, Jiang C, Liu P, Poutanen S, Penninger J, Butany J (2009) SARS-coronavirus modulation of myocardial ACE2 expression and inflammation in patients with SARS. Eur J Clin Invest 39(7):618-625

71. Liu F, Long X, Zhang B, Zhang W, Chen X, Zhang Z (2020) ACE2 expression in pancreas may cause pancreatic damage after SARS-CoV-2 infection. Clin Gastroenterol Hepatol 18(9):21282130.e2122

72. Gomez-Pinedo U, Matias-Guiu J, Sanclemente-Alaman I, Moreno-Jimenez L, Montero-Escribano P, Matias-Guiu JA (2020) Is the brain a reservoir organ for SARS-CoV2? J Med Virol 92(11):2354-2355

73. Liu Y, Sun W, Guo Y, Chen L, Zhang L, Zhao S, Long D, Yu L (2020) Association between platelet parameters and mortality in coronavirus disease 2019: retrospective cohort study. Platelets 31(4):490-496
74. Betakova T, Kostrábová A, Lachova V, Turianová L (2017) Cytokines induced during influenza virus infection. Curr Pharm Des 23(18):2616-2622

75. Freeman CM, Martinez FJ, Han MK, Ames TM, Chensue SW, Todt JC, Arenberg DA, Meldrum CA, Getty C, McCloskey L (2009) Lung dendritic cell expression of maturation molecules increases with worsening chronic obstructive pulmonary disease. Am J Respir Crit Care Med 180(12):1179-1188

76. Gu Y, Hsu AC-Y, Pang Z, Pan H, Zuo X, Wang G, Zheng J, Wang F (2019) Role of the innate cytokine storm induced by the influenza A virus. Viral Immunol 32(6):244-251

77. England JT, Abdulla A, Biggs CM, Lee AY, Hay KA, Hoiland RL, Wellington CL, Sekhon M, Jamal S, Shojania K (2020) Weathering the COVID-19 storm: lessons from hematologic cytokine syndromes. Blood Reviews 45:100707. https://doi.org/ 10.1016/j.blre.2020.10070

78. Moore JB, June CH (2020) Cytokine release syndrome in severe COVID-19. Science 368(6490):473-474

79. Zheng J (2020) SARS-CoV-2: an emerging coronavirus that causes a global threat. Int J Biol Sci 16(10):1678

80. Nikpouraghdam M, Farahani AJ, Alishiri G, Heydari S, Ebrahimnia M, Samadinia H, Sepandi M, Jafari NJ, Izadi M, Qazvini A (2020) Epidemiological characteristics of coronavirus disease 2019 (COVID-19) patients in IRAN: a single center study. J Clin Virol 127:104378

81. Huang J, Zheng M, Tang X, Chen Y, Tong A, Zhou L (2020) Potential of SARS-CoV-2 to cause CNS infection: biologic fundamental and clinical experience. Front Neurol 11:659

82. Huang C, Wang Y, Li X, Ren L, Zhao J, Hu Y, Zhang L, Fan G, Xu J, Gu X, Cheng Z, Yu T, Xia J, Wei Y, Wu W, Xie X, Yin W, Li H, Liu M, Xiao Y, Gao H, Guo L, Xie J, Wang G, Jiang R, Gao Z, Jin Q, Wang J, Cao B (2020) Clinical features of patients infected with 2019 novel coronavirus in Wuhan. China Lancet 395(10223):497-506. https://doi.org/10.1016/S0140-6736(20) 30183-5

83. Mao L, Jin H, Wang M, Hu Y, Chen S, He Q, Chang J, Hong C, Zhou Y, Wang D, Miao X, Li Y, Hu B (2020) Neurologic manifestations of hospitalized patients with coronavirus disease 2019 in Wuhan. China JAMA Neurol 77(6):683-690. https://doi.org/ 10.1001/jamaneurol.2020.1127

84. Wu Y, Xu X, Chen Z, Duan J, Hashimoto K, Yang L, Liu C, Yang C (2020) Nervous system involvement after infection with COVID-19 and other coronaviruses. Brain Behav Immun 87:18-22

85. Dube M, Le Coupanec A, Wong AHM, Rini JM, Desforges M, Talbot PJ (2018) Axonal transport enables neuron-to-neuron propagation of human coronavirus OC43. J Virol 92 (17). https:// doi.org/10.1128/JVI.00404-18

86. Talbot PJ, Ekande S, Cashman NR, Mounir S, Stewart JN (1993) Neurotropism of human coronavirus 229E. Adv Exp Med Biol 342:339-346. https://doi.org/10.1007/978-1-4615-2996-5_52

87. Li YC, Bai WZ, Hirano N, Hayashida T, Hashikawa T (2012) Coronavirus infection of rat dorsal root ganglia: ultrastructural characterization of viral replication, transfer, and the early response of satellite cells. Virus Res 163(2):628-635. https:// doi.org/10.1016/j.virusres.2011.12.021

88. Buzhdygan TP, DeOre BJ, Baldwin-Leclair A, Bullock TA, McGary HM, Khan JA, Razmpour R, Hale JF, Galie PA, Potula R (2020) The SARS-CoV-2 spike protein alters barrier function in 2D static and 3D microfluidic in-vitro models of the human blood-brain barrier. Neurobiol Dis 146:105131

89. Lu R, Zhao X, Li J, Niu P, Yang B, Wu H, Wang W, Song H, Huang B, Zhu N, Bi Y, Ma X, Zhan F, Wang L, Hu T, Zhou H, Hu Z, Zhou W, Zhao L, Chen J, Meng Y, Wang J, Lin Y, Yuan 
J, Xie Z, Ma J, Liu WJ, Wang D, Xu W, Holmes EC, Gao GF, Wu G, Chen W, Shi W, Tan W (2020) Genomic characterisation and epidemiology of 2019 novel coronavirus: implications for virus origins and receptor binding. Lancet 395(10224):565-574. https://doi.org/10.1016/S0140-6736(20)30251-8

90. Wan Y, Shang J, Graham R, Baric RS, Li F (2020) Receptor recognition by the novel coronavirus from Wuhan: an analysis based on decade-long structural studies of SARS coronavirus. J Virol 94 (7). https://doi.org/10.1128/JVI.00127-20

91. Kanberg N, Ashton NJ, Andersson L-M, Yilmaz A, Lindh M, Nilsson S, Price RW, Blennow K, Zetterberg H, Gisslén M (2020) Neurochemical evidence of astrocytic and neuronal injury commonly found in COVID-19. Neurology 95(12):e1754-e1759

92. Coolen T, Lolli V, Sadeghi N, Rovai A, Trotta N, Taccone FS, Creteur J, Henrard S, Goffard JC, Dewitte O, Naeije G, Goldman S, De Tiege X (2020) Early postmortem brain MRI findings in COVID-19 non-survivors. Neurology 95(14):e2016-e2027. https://doi.org/10.1212/WNL.0000000000010116

93. Helms J, Kremer S, Merdji H, Clere-Jehl R, Schenck M, Kummerlen C, Collange O, Boulay C, Fafi-Kremer S, Ohana M, Anheim M, Meziani F (2020) Neurologic features in severe SARS-CoV-2 infection. N Engl J Med 382(23):2268-2270. https://doi.org/10.1056/NEJMc2008597

94. Garg RK (2020) Spectrum of neurological manifestations in Covid-19: a review. Neurol India 68(3):560

95. Varatharaj A, Thomas N, Ellul MA, Davies NW, Pollak TA, Tenorio EL, Sultan M, Easton A, Breen G, Zandi M (2020) Neurological and neuropsychiatric complications of COVID-19 in 153 patients: a UK-wide surveillance study. The Lancet Psychiatry 7(10):875-882

96. Abdel-Mannan O, Eyre M, Löbel U, Bamford A, Eltze C, Hameed B, Hemingway C, Hacohen Y (2020) Neurologic and radiographic findings associated with COVID-19 infection in children. JAMA Neurol 77(11):1440-1445

97. Romero-Sánchez CM, Díaz-Maroto I, Fernández-Díaz E, Sánchez-Larsen Á, Layos-Romero A, García-García J, González E, Redondo-Peñas I, Perona-Moratalla AB, Del Valle-Pérez JA (2020) Neurologic manifestations in hospitalized patients with COVID-19: the ALBACOVID registry. Neurology 95(8):e1060-e1070

98. Kamil K, Yazid MD, Idrus RBH, Das S, Kumar J (2019) Peripheral demyelinating diseases: from biology to translational medicine. Front Neurol 10:87

99. Gowrisankar YV, Clark MA (2016) Angiotensin II regulation of angiotensin-converting enzymes in spontaneously hypertensive rat primary astrocyte cultures. J Neurochem 138(1):74-85

100. Li N, Ma WT, Pang M, Fan QL, Hua JL (2019) The commensal microbiota and viral infection: a comprehensive review. Front Immunol 10:1551. https://doi.org/10.3389/fimmu.2019.01551

101. Donoghue M, Hsieh F, Baronas E, Godbout K, Gosselin M, Stagliano N, Donovan M, Woolf B, Robison K, Jeyaseelan R, Breitbart RE, Acton S (2000) A novel angiotensin-converting enzyme-related carboxypeptidase (ACE2) converts angiotensin I to angiotensin 1-9. Circ Res 87(5):E1-9. https://doi.org/10.1161/01.res.87.5.e1

102. Hamming I, Timens W, Bulthuis ML, Lely AT, Navis G, van Goor H (2004) Tissue distribution of ACE2 protein, the functional receptor for SARS coronavirus. A first step in understanding SARS pathogenesis. J Pathol 203(2):631-637. https://doi. org/10.1002/path.1570

103. Xiao L, Haack KK, Zucker IH (2013) Angiotensin II regulates ACE and ACE2 in neurons through p38 mitogen-activated protein kinase and extracellular signal-regulated kinase $1 / 2$ signaling. Am J Physiol Cell Physiol 304(11):C1073-1079. https://doi. org/10.1152/ajpcell.00364.2012

104. Jarrahi A, Ahluwalia M, Khodadadi H, Salles EdSL, Kolhe R, Hess DC, Vale F, Kumar M, Baban B, Vaibhav K (2020)
Neurological consequences of COVID-19: what have we learned and where do we go from here? J Neuroinflammation 17(1):1-12

105. Yeh EA, Collins A, Cohen ME, Duffner PK, Faden H (2004) Detection of coronavirus in the central nervous system of a child with acute disseminated encephalomyelitis. Pediatrics $113(1 \mathrm{Pt}$ 1):e73-76. https://doi.org/10.1542/peds.113.1.e73

106. Hui DSC, Zumla A (2019) Severe acute respiratory syndrome: historical, epidemiologic, and clinical features. Infect Dis Clin North Am 33(4):869-889. https://doi.org/10.1016/j.idc.2019.07. 001

107. Gassen NC, Papies J, Bajaj T, Dethloff F, Emanuel J, Weckmann K, Heinz DE, Heinemann N, Lennarz M, Richter A (2020) Analysis of SARS-CoV-2-controlled autophagy reveals spermidine, MK-2206, and niclosamide as putative antiviral therapeutics. BioRxiv. https://doi.org/10.1101/2020.04.15.997254

108. Ll X, Shi F, Tan Z, Li Y, Bode AM, Cao Y (2018) Mitochondrial network structure homeostasis and cell death. Cancer Sci 109(12):3686-3694

109. Wang Y, Cao Y, Yamada S, Thirunavukkarasu M, Nin V, Joshi M, Rishi MT, Bhattacharya S, Camacho-Pereira J, Sharma AK (2015) Cardiomyopathy and worsened ischemic heart failure in SM22- $\alpha$ Cre-mediated neuropilin-1 null mice: dysregulation of PGC1 $\alpha$ and mitochondrial homeostasis. Arterioscler Thromb Vasc Biol 35(6):1401-1412

110. Chen K, Xu Z, Liu Y, Wang Z, Li Y, Xu X, Chen C, Xia T, Liao Q, Yao Y (2017) Irisin protects mitochondria function during pulmonary ischemia/reperfusion injury. Sci Transl Med 9(418):eaao6298. https://doi.org/10.1126/scitranslmed.aao62 98

111. de Oliveira M, De Sibio MT, Mathias LS, Rodrigues BM, Sakalem ME, Nogueira CR (2020) Irisin modulates genes associated with severe coronavirus disease (COVID-19) outcome in human subcutaneous adipocytes cell culture. Mol Cell Endocrinol 515:110917

112. Korta P, Pocheć E, Mazur-Biały A (2019) Irisin as a multifunctional protein: implications for health and certain diseases. Medicina 55(8):485

113. Nunn AV, Guy GW, Brysch W, Botchway SW, Frasch W, Calabrese EJ, Bell JD (2020) SARS-CoV-2 and mitochondrial health: implications of lifestyle and ageing. Immun Ageing 17(1):1-21

114. Monlun M, Hyernard C, Blanco P, Lartigue L, Faustin B (2017) Mitochondria as molecular platforms integrating multiple innate immune signalings. J Mol Biol 429(1):1-13

115. Tiku V, Tan M-W, Dikic I (2020) Mitochondrial functions in infection and immunity. Trends Cell Biol 30(4):263-275

116. Nunn AV, Bell JD, Guy GW (2009) Lifestyle-induced metabolic inflexibility and accelerated ageing syndrome: insulin resistance, friend or foe? Nutr Metab 6(1):1-26

117. van der Zalm I, van der Valk E, Wester V, Nagtzaam N, van Rossum E, Leenen P, Dik W (2020) Obesity-associated T-cell and macrophage activation improve partly after a lifestyle intervention. Int J Obes 44(9): 1838-1850

118. Petersen AMW, Pedersen BK (2005) The anti-inflammatory effect of exercise. J Appl Physiol 98(4):1154-1162

119. Yu L, Chen X, Wang L, Chen S (2018) Oncogenic virus-induced aerobic glycolysis and tumorigenesis. J Cancer 9(20):3699

120. Leon J, Acuña-Castroviejo D, Sainz RM, Mayo JC, Tan D-X, Reiter RJ (2004) Melatonin and mitochondrial function. Life Sci 75(7):765-790

121. Reiter RJ, Sharma R, Ma Q, Dominquez-Rodriguez A, Marik PE, Abreu-Gonzalez P (2020) Melatonin inhibits COVID-19-induced cytokine storm by reversing aerobic glycolysis in immune cells: a mechanistic analysis. Medicine in drug discovery 6:100044

122. Calabrese V, Cornelius C, Dinkova-Kostova AT, Calabrese EJ, Mattson MP (2010) Cellular stress responses, the hormesis 
paradigm, and vitagenes: novel targets for therapeutic intervention in neurodegenerative disorders. Antioxid Redox Signal 13(11):1763-1811

123. Kennedy RB, Ovsyannikova IG, Haralambieva IH, Oberg AL, Zimmermann MT, Grill DE, Poland GA (2016) Immunosenescence-related transcriptomic and immunologic changes in older individuals following influenza vaccination. Front Immunol 7:450

124. Takeda Y, Jamsransuren D, Matsuda S, Crea R, Ogawa H (2021) The SARS-CoV-2-inactivating activity of hydroxytyrosol-rich aqueous olive pulp extract (HIDROX®) and its use as a virucidal cream for topical application. Viruses 13(2):232

125. Brunetti G, Di Rosa G, Scuto M, Leri M, Stefani M, SchmitzLinneweber C, Calabrese V, Saul N (2020) Healthspan maintenance and prevention of Parkinson's-like phenotypes with hydroxytyrosol and oleuropein aglycone in C. elegans. Int J Mol Sci 21(7):2588

126. Siracusa R, Fusco R, Peritore AF, Cordaro M, D'Amico R, Genovese T, Gugliandolo E, Crupi R, Smeriglio A, Mandalari $\mathrm{G}$ (2020) The antioxidant and anti-inflammatory properties of Anacardium occidentale L. cashew nuts in a mouse model of colitis. Nutrients 12(3):834

127. Frasca D, Blomberg BB (2020) The impact of obesity and metabolic syndrome on vaccination success. Vaccines for older adults 43:86-97

128. Oxley TJ, Mocco J, Majidi S, Kellner CP, Shoirah H, Singh IP, De Leacy RA, Shigematsu T, Ladner TR, Yaeger KA, Skliut M, Weinberger J, Dangayach NS, Bederson JB, Tuhrim S, Fifi JT (2020) Large-vessel stroke as a presenting feature of Covid-19 in the young. N Engl J Med 382(20):e60. https://doi.org/10.1056/NEJMc2009787

129. Pleasure SJ, Green AJ, Josephson SA (2020) The spectrum of neurologic disease in the severe acute respiratory syndrome coronavirus 2 pandemic infection: neurologists move to the frontlines. JAMA Neurol 77(6):679-680. https://doi.org/10.1001/jaman eurol.2020.1065

130. Yavarpour-Bali H, Ghasemi-Kasman M (2020) Update on neurological manifestations of COVID-19. Life Sciences 257:118063. https://doi.org/10.1016/j.lfs.2020.118063

131. Nemoto W, Yamagata R, Nakagawasai O, Nakagawa K, Hung W-Y, Fujita M, Tadano T, Tan-No K (2020) Effect of spinal angiotensin-converting enzyme 2 activation on the formalin-induced nociceptive response in mice. Eur J Pharmacol 872:172950

132. Zhao K, Huang J, Dai D, Feng Y, Liu L, Nie S (2020) Acute myelitis after SARS-CoV-2 infection: a case report. MedRxiv. https://doi.org/10.1101/2020.03.16.20035105

133. Netland J, Meyerholz DK, Moore S, Cassell M, Perlman S (2008) Severe acute respiratory syndrome coronavirus infection causes neuronal death in the absence of encephalitis in mice transgenic for human ACE2. J Virol 82(15):7264-7275. https://doi.org/10. 1128/JVI.00737-08

134. Butowt R, Bilinska K (2020) SARS-CoV-2: olfaction, brain infection, and the urgent need for clinical samples allowing earlier virus detection. ACS Chem Neurosci 11(9):1200-1203

135. Harberts E, Yao K, Wohler JE, Maric D, Ohayon J, Henkin R, Jacobson S (2011) Human herpesvirus-6 entry into the central nervous system through the olfactory pathway. Proc Natl Acad Sci U S A 108(33):13734-13739. https://doi.org/10.1073/pnas. 1105143108

136. Attoub S, Hassan AH, Vanhoecke B, Iratni R, Takahashi T, Gaben A-M, Bracke M, Awad S, John A, Kamalboor HA (2011) Inhibition of cell survival, invasion, tumor growth and histone deacetylase activity by the dietary flavonoid luteolin in human epithelioid cancer cells. Eur J Pharmacol 651(1-3):18-25

137. Chow CCN, Magnussen J, Ip J, Su Y (2020) Acute transverse myelitis in COVID-19 infection. BMJ Case Reports CP 13(8):e236720
138. Rietdijk CD, Perez-Pardo P, Garssen J, van Wezel RJ, Kraneveld AD (2017) Exploring Braak's hypothesis of Parkinson's disease. Front Neurol 8:37. https://doi.org/10.3389/fneur.2017.00037

139. Yang X, Yu Y, Xu J, Shu H, Xia J, Liu H, Wu Y, Zhang L, Yu Z, Fang M, Yu T, Wang Y, Pan S, Zou X, Yuan S, Shang Y (2020) Clinical course and outcomes of critically ill patients with SARSCoV-2 pneumonia in Wuhan, China: a single-centered, retrospective, observational study. Lancet Respir Med 8(5):475-481. https://doi.org/10.1016/S2213-2600(20)30079-5

140. Libbey JE, Kennett NJ, Wilcox KS, White HS, Fujinami RS (2011) Interleukin-6, produced by resident cells of the central nervous system and infiltrating cells, contributes to the development of seizures following viral infection. J Virol 85(14):69136922. https://doi.org/10.1128/JVI.00458-11

141. Singhi $P$ (2011) Infectious causes of seizures and epilepsy in the developing world. Dev Med Child Neurol 53(7):600-609. https:// doi.org/10.1111/j.1469-8749.2011.03928.x

142. Pilotto A, Odolini S, Masciocchi S, Comelli A, Volonghi I, Gazzina S, Nocivelli S, Pezzini A, Foca E, Caruso A, Leonardi M, Pasolini MP, Gasparotti R, Castelli F, Ashton NJ, Blennow K, Zetterberg H, Padovani A (2020) Steroid-responsive encephalitis in coronavirus disease 2019. Ann Neurol 88(2):423-427. https:// doi.org/10.1002/ana.25783

143. Durrani M, Kucharski K, Smith Z, Fien S (2020) Acute transverse myelitis secondary to severe acute respiratory syndrome coronavirus 2 (SARS-CoV-2): a case report. Clin Pract Cases Emerg Med 4(3):344-348. https://doi.org/10.5811/cpcem.2020.6.48462

144. Mehta P, McAuley DF, Brown M, Sanchez E, Tattersall RS, Manson JJ, Collaboration HAS, UK, (2020) COVID-19: consider cytokine storm syndromes and immunosuppression. Lancet 395(10229):1033-1034. https://doi.org/10.1016/S0140-6736(20) 30628-0

145. Soler ZM, Patel ZM, Turner JH, Holbrook EH. A primer on viralassociated olfactory loss in the era of COVID-19. International Forum of Allergy \& Rhinology 10(7): 814-820. https://doi.org/ 10.1002/alr.22578

146. Vaira LA, Salzano G, Fois AG, Piombino P, De Riu G (2020) Potential pathogenesis of ageusia and anosmia in COVID-19 patients. Int Forum Allergy Rhinol 10(9):1103-1104. https:// doi.org/10.1002/alr.22593

147. Liu Y-Z, Wang Y-X, Jiang C-L (2017) Inflammation: the common pathway of stress-related diseases. Front Hum Neurosci $11: 316$

148. Vriend C, Pattij T, van der Werf YD, Voorn P, Booij J, Rutten S, Berendse HW, van den Heuvel OA (2014) Depression and impulse control disorders in Parkinson's disease: two sides of the same coin? Neurosci Biobehav Rev 38:60-71

149. Zach H, Dirkx MF, Pasman JW, Bloem BR, Helmich RC (2017) Cognitive stress reduces the effect of levodopa on Parkinson's resting tremor. CNS Neurosci Ther 23(3):209-215. https://doi. org/10.1111/cns. 12670

150. Ehgoetz Martens KA, Hall JM, Georgiades MJ, Gilat M, Walton CC, Matar E, Lewis SJG, Shine JM (2018) The functional network signature of heterogeneity in freezing of gait. Brain 141(4):1145-1160. https://doi.org/10.1093/brain/awy019

151. Macht M, Kaussner Y, Moller JC, Stiasny-Kolster K, Eggert KM, Kruger HP, Ellgring H (2007) Predictors of freezing in Parkinson's disease: a survey of 6,620 patients. Mov Disord 22(7):953-956. https://doi.org/10.1002/mds.21458

152. Zach H, Dirkx M, Pasman JW, Bloem BR, Helmich RC (2017) The patient's perspective: the effect of levodopa on Parkinson symptoms. Parkinsonism Relat Disord 35:48-54. https://doi.org/ 10.1016/j.parkreldis.2016.11.015

153. Nataf $S$ (2020) An alteration of the dopamine synthetic pathway is possibly involved in the pathophysiology of COVID-19. J Med Virol 92(10):1743-1744 
154. Silhol F, Sarlon G, Deharo J-C, Vaïsse B (2020) Downregulation of ACE2 induces overstimulation of the renin-angiotensin system in COVID-19: should we block the renin-angiotensin system? Hypertension Research: Official Journal of the Japanese Society of Hypertension 43(8):854-856. https://doi.org/10.1038/ s41440-020-0476-3

155. Carod-Artal FJ (2020) Neurological complications of coronavirus and COVID-19. Rev Neurol 70(9):311-322. https://doi.org/10. 33588/rn.7009.2020179

156. Barzegar M, Mirmosayyeb O, Nehzat N, Sarrafi R, Khorvash F, Maghzi AH, Shaygannejad V (2020) COVID-19 infection in a patient with multiple sclerosis treated with fingolimod. Neurol Neuroimmunol Neuroinflamm 7(4). https://doi.org/10.1212/NXI. 0000000000000753

157. Foerch C, Friedauer L, Bauer B, Wolf T, Adam EH (2020) Severe COVID-19 infection in a patient with multiple sclerosis treated with fingolimod. Mult Scler Relat Disord 42:102180. https://doi. org/10.1016/j.msard.2020.102180

158. Berger JR, Brandstadter R, Bar-Or A (2020) COVID-19 and MS disease-modifying therapies. Neurology-Neuroimmunology Neuroinflammation 7(4):e761. https://doi.org/10.1212/ NXI.0000000000000761

159. Abate G, Memo M, \& Uberti D (2020) Impact of COVID-19 on alzheimer's Disease Risk: Viewpoint for Research Action. Healthcare (Basel, Switzerland) 8(3):286. https://doi.org/10. 3390/healthcare 8030286

160. Selkoe DJ, Hardy J (2016) The amyloid hypothesis of Alzheimer's disease at 25 years. EMBO Mol Med 8(6):595-608

161. Serrano-Pozo A, Frosch MP, Masliah E, Hyman BT (2011) Neuropathological alterations in Alzheimer disease. Cold Spring Harb Perspect Med 1(1):a006189. https://doi.org/10. 1101/cshperspect.a006189

162. Soscia SJ, Kirby JE, Washicosky KJ, Tucker SM, Ingelsson M, Hyman B, Burton MA, Goldstein LE, Duong S, Tanzi RE (2010) The Alzheimer's disease-associated amyloid $\beta$-protein is an antimicrobial peptide. PLoS ONE 5(3):e9505

163. Caress JB, Castoro RJ, Simmons Z, Scelsa SN, Lewis RA, Ahlawat A, Narayanaswami P (2020) COVID-19-associated GuillainBarré syndrome: the early pandemic experience. Muscle Nerve 62(4):485-491

164. Lunn MP, Cornblath DR, Jacobs BC, Querol L, van Doorn PA, Hughes RA, Willison HJ (2021) COVID-19 vaccine and Guillain-Barré syndrome: let's not leap to associations. Brain 144(2):357-360

165. Haber P, Sejvar J, Mikaeloff Y, DeStefano F (2009) Vaccines and Guillain-Barre syndrome. Drug Saf 32(4):309-323

166. Zhao H, Shen D, Zhou H, Liu J, Chen S (2020) Guillain-Barré syndrome associated with SARS-CoV-2 infection: causality or coincidence? Lancet Neurol 19(5):383-384

167. Bhandari R, Khanna G, Kaushik D, Kuhad A (2021) Divulging the intricacies of crosstalk between NF-Kb and Nrf2Keap1 pathway in neurological complications of COVID19. Molecular Neurobiology:1-15. https://doi.org/10.1007/ s12035-021-02344-7

168. Toscano G, Palmerini F, Ravaglia S, Ruiz L, Invernizzi P, Cuzzoni MG, Franciotta D, Baldanti F, Daturi R, Postorino P (2020) Guillain-Barré syndrome associated with SARS-CoV-2. N Engl J Med 382(26):2574-2576

169. Gutiérrez-Ortiz C, Méndez-Guerrero A, Rodrigo-Rey S, San Pedro-Murillo E, Bermejo-Guerrero L, Gordo-Mañas R, de Aragón-Gómez F, Benito-León J (2020) Miller Fisher Syndrome and polyneuritis cranialis in COVID-19. Neurology 95(5):e601-e605

170. Pfefferkorn T, Dabitz R, von Wernitz-Keibel T, Aufenanger J, Nowak-Machen M, Janssen H (2020) Acute polyradiculoneuritis with locked-in syndrome in a patient with Covid-19. J Neurol 267:1883-1884

171. Waheed S, Bayas A, Hindi F, Rizvi Z, Espinosa PS (2021) Neurological complications of COVID-19: Guillain-Barre syndrome following Pfizer COVID-19 vaccine. Cureus 13(2):e13426. https://doi.org/10.7759/cureus

172. Parsons T, Banks S, Bae C, Gelber J, Alahmadi H, Tichauer M (2020) COVID-19-associated acute disseminated encephalomyelitis (ADEM). J Neurol 267:2799-2802

173. Mao L, Jin H, Wang M, Hu Y, Chen S, He Q, Chang J, Hong C, Zhou Y, Wang D (2020) Neurologic manifestations of hospitalized patients with coronavirus disease 2019 in Wuhan, China. JAMA Neurol 77(6):683-690

174. Madia F, Merico B, Primiano G, Cutuli SL, De Pascale G, Servidei S (2020) Acute myopathic quadriplegia in patients with COVID-19 in the intensive care unit. Neurology 95(11):492-494

175. Tankisi H, Tankisi A, Harbo T, Markvardsen L, Andersen H, Pedersen T (2020) Critical illness myopathy as a consequence of Covid 19 infection. Clin Neurophysiol 131(8):1931

176. Cockrell AS, Leist SR, Douglas MG, Baric RS (2018) Modeling pathogenesis of emergent and pre-emergent human coronaviruses in mice. Mamm Genome 29(7-8):367-383

177. McKee DL, Sternberg A, Stange U, Laufer S, Naujokat C (2020) Candidate drugs against SARS-CoV-2 and COVID-19. Pharmacological Research 157:104859. https://doi.org/10.1016/j.phrs. 2020.104859

178. Wang X, Xia S, Zhu Y, Lu L, Jiang S (2021) Pan-coronavirus fusion inhibitors as the hope for today and tomorrow. Protein \& Cell 12(2):84-88. https://doi.org/10.1007/s13238-020-00806-7

179. Pantelis C, Jayaram M, Hannan AJ, Wesselingh R, Nithianantharajah J, Wannan CM, Syeda WT, Choy KC, Zantomio D, Christopoulos A, Velakoulis D, O'Brien T J (2020) Neurological, Neuropsychiatric and Neurodevelopmental Complications of COVID-19. Aust NZ J Psychiatry 0004867420961472. https:// doi.org/10.1177/0004867420961472

180. Rabaan AA, Al-Ahmed SH, Haque S, Sah R, Tiwari R, Malik YS, Dhama K, Yatoo MI, Bonilla-Aldana DK, RodriguezMorales AJ (2020) SARS-CoV-2, SARS-CoV, and MERS-CoV: a comparative overview. Infez Med 28(2):174-184

181. Gomez-Pinedo U, Matias-Guiu J, Sanclemente-Alaman I, Moreno-Jimenez L, Montero-Escribano P (2020) SARS-CoV2 as a potential trigger of neurodegenerative diseases. Movement Disorders

182. Ramani A, Müller L, Ostermann PN, Gabriel E, Abida-Islam P, Müller-Schiffmann A, Mariappan A, Goureau O, Gruell H, Walker A, Andrée M, Hauka S, Houwaart T, Dilthey A, Wohlgemuth K, Omran H, Klein F, Wieczorek D, Adams O, Timm J, ... Gopalakrishnan J (2020) SARS-CoV-2 targets neurons of 3D human brain organoids. The EMBO Journal 39(20):e106230. https://doi.org/10.15252/embj.2020106230

183. Song E, Zhang C, Israelow B, Lu-Culligan A, Prado AV, Skriabine S, Lu P, Weizman OE, Liu F, Dai Y, Szigeti-Buck K, Yasumoto Y, Wang G, Castaldi C, Heltke J, Ng E, Wheeler J, Alfajaro MM, Levavasseur E, Fontes B, ... Iwasaki A (2020) Neuroinvasive potential of SARS-CoV-2 revealed in a human brain organoid model. bioRxiv:the preprint server for biology, 2020.06.25.169946. https://doi.org/10.1101/2020.06.25.169946

184. Yang L, Han Y, Nilsson-Payant BE, Gupta V, Wang P, Duan $X$, Tang X, Zhu J, Zhao Z, Jaffré F (2020) A human pluripotent stem cell-based platform to study SARS-CoV-2 tropism and model virus infection in human cells and organoids. Cell stem cell 27(1):125-136.e127

185. Post GR, Dawson G (1992) Characterization of a cell line derived from a human oligodendroglioma. Mol Chem Neuropathol 16(3):303-317 
186. De Kleijn K, Zuure WA, Peijnenborg J, Heuvelmans JM, Martens GJ (2019) Reappraisal of human HOG and MO3. 13 cell lines as a model to study oligodendrocyte functioning. Cells 8(9):1096

187. Benda P, Lightbody J, Sato G, Levine L, Sweet W (1968) Differentiated rat glial cell strain in tissue culture. Science 161(3839):370-371

188. Yamashita M, Yamate M, Li G-M, Ikuta K (2005) Susceptibility of human and rat neural cell lines to infection by SARS-coronavirus. Biochem Biophys Res Commun 334(1):79-85

189. Arbour N, Côté G, Lachance C, Tardieu M, Cashman NR, Talbot PJ (1999) Acute and persistent infection of human neural cell lines by human coronavirus OC43. J Virol 73(4):3338-3350

190. Favreau DJ, Meessen-Pinard M, Desforges M, Talbot PJ (2012) Human coronavirus-induced neuronal programmed cell death is cyclophilin d dependent and potentially caspase dispensable. $\mathbf{J}$ Virol 86(1):81-93

191. Lachance C, Arbour N, Cashman NR, Talbot PJ (1998) Involvement of aminopeptidase N (CD13) in infection of human neural cells by human coronavirus 229E. J Virol 72(8):6511-6519

192. Meessen-Pinard M, Le Coupanec A, Desforges M, Talbot PJ (2016) Pivotal role of receptor-interacting protein kinase 1 and mixed lineage kinase domain-like in neuronal cell death induced by the human neuroinvasive coronavirus OC43. J Virol 91(1):e01513-16. https://doi.org/10.1128/JVI.01513-16

193. St-Jean JR, Desforges M, Talbot PJ (2006) Genetic evolution of human coronavirus OC43 in neural cell culture. Adv Exp Med Biol 581:499-502. https://doi.org/10.1007/978-0-387-33012-9_88

194. Fatehullah A, Tan SH, Barker N (2016) Organoids as an in vitro model of human development and disease. Nat Cell Biol 18(3):246-254

195. Dutta D, Heo I, Clevers H (2017) Disease modeling in stem cell-derived 3D organoid systems. Trends Mol Med 23(5):393-410

196. Rossi G, Manfrin A, Lutolf MP (2018) Progress and potential in organoid research. Nat Rev Genet 19(11):671-687

197. Busquet F, Hartung T, Pallocca G, Rovida C, Leist M (2020) Harnessing the power of novel animal-free test methods for the development of COVID-19 drugs and vaccines. Arch Toxicol 94(6):2263-2272. https://doi.org/10.1007/s00204-020-02787-2

198. Takayama K (2020) In vitro and animal models for SARS-CoV-2 research. Trends Pharmacol Sci 41(8):513-517

199. Harschnitz O, Studer L (2021) Human stem cell models to study host-virus interactions in the central nervous system. Nature reviews. Immunology 10.1038/s41577-020-00474-y. https://doi. org/10.1038/s41577-020-00474-y

200. Bullen CK, Hogberg HT, Bahadirli-Talbott A, Bishai WR, Hartung T, Keuthan C, Looney MM, Pekosz A, Romero JC, Sillé FC (2020) Infectability of human BrainSphere neurons suggests neurotropism of SARS-CoV-2. ALTEX-Alternatives to animal experimentation 37(4):665-671

201. Mesci P, Macia A, Saleh A, Martin-Sancho L, Yin X, Snethlage C, Avansini S, Chanda S, Muotri A (2020) Sofosbuvir protects human brain organoids against SARS-CoV-2. bioRxiv. https:// doi.org/10.1101/2020.05.30.125856

202. Sayad B, Sobhani M, Khodarahmi R (2020) Sofosbuvir as repurposed antiviral drug against COVID-19: why were we convinced to evaluate the drug in a registered/approved clinical trial? Arch Med Res 51(6):577-581

203. Simoneau CR, Ott M (2020) Modeling multi-organ infection by SARS-CoV-2 using stem cell technology. Cell Stem Cell 27(6):859-868

204. Walsh KB, Edwards RA, Romero KM, Kotlajich MV, Stohlman SA, Lane TE (2007) Expression of CXC chemokine ligand 10 from the mouse hepatitis virus genome results in protection from viral-induced neurological and liver disease. J Immunol 179(2):1155-1165
205. Savarin C, Bergmann CC (2018) Fine tuning the cytokine storm by IFN and IL-10 following neurotropic coronavirus encephalomyelitis. Front Immunol 9:3022

206. Wege H, Stühler A, Lassmann H, Wege H (1998) Coronavirus infection and demyelination. Sequence conservation of the S-gene during persistent infection of Lewis-rats. Advances in Experimental Medicine and Biology 440:767-773

207. Zalinger ZB, Elliott R, Weiss SR (2017) Role of the inflammasome-related cytokines Il-1 and Il-18 during infection with murine coronavirus. J Neurovirol 23(6):845-854

208. Gruslin E, Moisan S, St-Pierre Y, Desforges M, Talbot PJ (2005) Transcriptome profile within the mouse central nervous system and activation of myelin-reactive $\mathrm{T}$ cells following murine coronavirus infection. J Neuroimmunol 162(1-2):60-70

209. Choi KS, Aizaki H, Lai MM (2005) Murine coronavirus requires lipid rafts for virus entry and cell-cell fusion but not for virus release. J Virol 79(15):9862-9871

210. Singh M, Khan RS, Dine K, Das Sarma J, Shindler KS (2018) Intracranial inoculation is more potent than intranasal inoculation for inducing optic neuritis in the mouse hepatitis virus-induced model of multiple sclerosis. Front Cell Infect Microbiol 8:311

211. Wang F-I, Stohlman SA, Fleming JO (1990) Demyelination induced by murine hepatitis virus JHM strain (MHV-4) is immunologically mediated. J Neuroimmunol 30(1):31-41

212. Dandekar AA, Perlman S (2002) Virus-induced demyelination in nude mice is mediated by $\gamma \delta \mathrm{T}$ cells. Am J Pathol 161(4):1255-1263

213. Glass WG, Chen BP, Liu MT, Lane TE (2002) Mouse hepatitis virus infection of the central nervous system: chemokinemediated regulation of host defense and disease. Viral Immunol 15(2):261-272

214. Hosking MP, Lane TE (2010) The pathogenesis of murine coronavirus infection of the central nervous system. Crit Rev Immunol 30(2):119-130. https://doi.org/10.1615/critrevimmunol.v30. i 2.20

215. Madjunkov M, Dviri M, Librach C (2020) A comprehensive review of the impact of COVID-19 on human reproductive biology, assisted reproduction care and pregnancy: a Canadian perspective. J Ovarian Res 13(1):1-18

216. Meyer U (2019) Neurodevelopmental resilience and susceptibility to maternal immune activation. Trends Neurosci 42(11):793-806

217. Choi GB, Yim YS, Wong H, Kim S, Kim H, Kim SV, Hoeffer CA, Littman DR, Huh JR (2016) The maternal interleukin-17a pathway in mice promotes autism-like phenotypes in offspring. Science 351(6276):933-939

218. UK G (2020) COVID-19: investigation and initial clinical management of possible cases. Gov Uk:1-5

219. Alhazzani W, Møller MH, Arabi YM, Loeb M, Gong MN, Fan E, Oczkowski S, Levy MM, Derde L, Dzierba A, Du B, Aboodi M, Wunsch H, Cecconi M, Koh Y, Chertow DS, Maitland K, Alshamsi F, Belley-Cote E, Greco M, ... Rhodes A (2020) Surviving sepsis campaign: guidelines on the management of critically ill adults with Coronavirus Disease 2019 (COVID-19). Intensive Care Medicine 46(5):854-887. https://doi.org/10.1007/ s00134-020-06022-5

220. Li F (2016) Structure, function, and evolution of coronavirus spike proteins. Annu Rev Virol 3:237-261

221. Malik YS, Sircar S, Bhat S, Sharun K, Dhama K, Dadar M, Tiwari R, Chaicumpa W (2020) Emerging novel coronavirus (2019-nCoV)—current scenario, evolutionary perspective based on genome analysis and recent developments. Veterinary Quarterly 40(1):68-76

222. Fang L, Karakiulakis G, Roth M (2020) Are patients with hypertension and diabetes mellitus at increased risk for COVID-19 infection? Lancet Respir Med 8(4):e21 
223. Ferrario CM, Jessup J, Chappell MC, Averill DB, Brosnihan KB, Tallant EA, Diz DI, Gallagher PE (2005) Effect of angiotensinconverting enzyme inhibition and angiotensin II receptor blockers on cardiac angiotensin-converting enzyme 2. Circulation 111(20):2605-2610

224. Gao Y, Yan L, Huang Y, Liu F, Zhao Y, Cao L, Wang T, Sun Q, Ming Z, Zhang L (2020) Structure of the RNA-dependent RNA polymerase from COVID-19 virus. Science 368(6492):779-782

225. Gorbalenya A, Baker S, Baric R, de Groot R, Drosten C, Gulyaeva A, Haagmans B, Lauber C, Leontovich A, Neuman B (2020) The species severe acute respiratory syndrome related coronavirus: classifying 2019-nCoV and naming it SARS-CoV-2. Nat Microbiol 5:536-544

226. Xia S, Zhu Y, Liu M, Lan Q, Xu W, Wu Y, Ying T, Liu S, Shi Z, Jiang S, \& Lu L (2020) Fusion mechanism of 2019-nCoV and fusion inhibitors targeting HR1 domain in spike protein. Cellular \& Molecular Immunology 17(7):765-767. https://doi.org/ 10.1038/s41423-020-0374-2

227. Zhou P, Yang X-L, Wang X-G, Hu B, Zhang L, Zhang W, Si H-R, Zhu Y, Li B, Huang C-L (2020) A pneumonia outbreak associated with a new coronavirus of probable bat origin. Nature 579(7798):270-273

228. Tian X, Li C, Huang A, Xia S, Lu S, Shi Z, Lu L, Jiang S, Yang Z, Wu Y (2020) Potent binding of 2019 novel coronavirus spike protein by a SARS coronavirus-specific human monoclonal antibody. Emerg Microbes Infect 9(1):382-385

229. Walls AC, Xiong X, Park Y-J, Tortorici MA, Snijder J, Quispe J, Cameroni E, Gopal R, Dai M, Lanzavecchia A (2019) Unexpected receptor functional mimicry elucidates activation of coronavirus fusion. Cell 176(5):1026-1039.e1015

230. Yan R, Zhang Y, Li Y, Xia L, Guo Y, Zhou Q (2020) Structural basis for the recognition of SARS-CoV-2 by full-length human ACE2. Science 367(6485):1444-1448

231. Glowacka I, Bertram S, Müller MA, Allen P, Soilleux E, Pfefferle S, Steffen I, Tsegaye TS, He Y, Gnirss K (2011) Evidence that TMPRSS 2 activates the severe acute respiratory syndrome coronavirus spike protein for membrane fusion and reduces viral control by the humoral immune response. J Virol 85(9):4122-4134

232. Shulla A, Heald-Sargent T, Subramanya G, Zhao J, Perlman S, Gallagher T (2011) A transmembrane serine protease is linked to the severe acute respiratory syndrome coronavirus receptor and activates virus entry. J Virol 85(2):873-882

233. Kleine-Weber H, Elzayat M, Hoffmann M, Pöhlmann S (2018) Functional analysis of potential cleavage sites in the MERScoronavirus spike protein. Sci Rep 8:16597

234. Park J-E, Li K, Barlan A, Fehr AR, Perlman S, McCray PB, Gallagher T (2016) Proteolytic processing of Middle East respiratory syndrome coronavirus spikes expands virus tropism. Proc Natl Acad Sci 113(43):12262-12267

235. Kawase M, Shirato K, van der Hoek L, Taguchi F, Matsuyama S (2012) Simultaneous treatment of human bronchial epithelial cells with serine and cysteine protease inhibitors prevents severe acute respiratory syndrome coronavirus entry. J Virol 86(12):6537-6545

236. Zhou Y, Vedantham P, Lu K, Agudelo J, Carrion R Jr, Nunneley JW, Barnard D, Pöhlmann S, McKerrow JH, Renslo AR (2015) Protease inhibitors targeting coronavirus and filovirus entry. Antiviral Res 116:76-84

237. Le TT, Cramer JP, Chen R, Mayhew S (2020) Evolution of the COVID-19 vaccine development landscape. Nat Rev Drug Discov 19(10):667-668

238. Deng Y, Lan J, Bao L, Huang B, Ye F, Chen Y, Yao Y, Wang W, Qin C, Tan W (2018) Enhanced protection in mice induced by immunization with inactivated whole viruses compare to spike protein of Middle East respiratory syndrome coronavirus. Emerg Microbes Infect 7(1):1-10
239. Tse LV, Meganck RM, Graham RL, Baric RS (2020) The current and future state of vaccines, antivirals and gene therapies against emerging coronaviruses. Front Microbiol 11:658

240. Lan J, Yao Y, Deng Y, Chen H, Lu G, Wang W, Bao L, Deng W, Wei Q, Gao GF (2015) Recombinant receptor binding domain protein induces partial protective immunity in rhesus macaques against Middle East respiratory syndrome coronavirus challenge. EBioMedicine 2(10): 1438-1446

241. Wang Y, Tai W, Yang J, Zhao G, Sun S, Tseng C-TK, Jiang S, Zhou Y, Du L, Gao J (2017) Receptor-binding domain of MERS$\mathrm{CoV}$ with optimal immunogen dosage and immunization interval protects human transgenic mice from MERS-CoV infection. Hum Vaccin Immunother 13(7):1615-1624

242. Zhang N, Channappanavar R, Ma C, Wang L, Tang J, Garron T, Tao X, Tasneem S, Lu L, Tseng C-TK (2016) Identification of an ideal adjuvant for receptor-binding domain-based subunit vaccines against Middle East respiratory syndrome coronavirus. Cell Mol Immunol 13(2):180-190

243. Du L, Zhao G, Chan CC, Sun S, Chen M, Liu Z, Guo H, He Y, Zhou Y, Zheng B-J (2009) Recombinant receptor-binding domain of SARS-CoV spike protein expressed in mammalian, insect and E. coli cells elicits potent neutralizing antibody and protective immunity. Virology 393(1):144-150

244. He Y, Zhou Y, Liu S, Kou Z, Li W, Farzan M, Jiang S (2004) Receptor-binding domain of SARS-CoV spike protein induces highly potent neutralizing antibodies: implication for developing subunit vaccine. Biochem Biophys Res Commun 324(2):773-781

245. Martínez-Sánchez G, Schwartz A, Di Donna V (2020) Potential cytoprotective activity of ozone therapy in SARS-CoV-2/ COVID-19. Antioxidants 9(5):389

246. Venkataraman T, Frieman MB (2017) The role of epidermal growth factor receptor (EGFR) signaling in SARS coronavirusinduced pulmonary fibrosis. Antiviral Res 143:142-150

247. Khan G (2013) A novel coronavirus capable of lethal human infections: an emerging picture. Virol J 10(1):1-6

248. Bocci V (2005) Ozone a new medical drug. Springer

249. Simonetti V, Quagliariello V, Franzini M, Iaffaioli RV, Maurea N, Valdenassi L (2019) Ozone exerts cytoprotective and antiinflammatory effects in cardiomyocytes and skin fibroblasts after incubation with doxorubicin. Evidence-Based Complementary and Alternative Medicine:eCAM 2019:2169103. https://doi.org/ $10.1155 / 2019 / 2169103$

250. Delgado-Roche L, Hernández-Matos Y, Medina EA, Morejón DÁ, González MR, Martínez-Sánchez G (2014) Ozone-oxidative preconditioning prevents doxorubicin-induced cardiotoxicity in Sprague-Dawley Rats. Sultan Qaboos Univ Med J 14(3):e342

251. Adali Y, Eroğlu HA, Makav M, Guvendi GF (2019) Efficacy of ozone and selenium therapy for alcoholic liver injury: an experimental model. in vivo 33(3):763-769

252. Tezcan AH, Ozturk O, Ustebay S, Adali Y, Yagmurdur H (2018) The beneficial effects of ozone therapy in acetaminopheninduced hepatotoxicity in mice. Pharmacol Rep 70(2):340-345

253. Wang L, Chen H, Liu X-H, Chen Z-Y, Weng X-D, Qiu T, Liu L, Zhu H-C (2014) Ozone oxidative preconditioning inhibits renal fibrosis induced by ischemia and reperfusion injury in rats. Exp Ther Med 8(6):1764-1768

254. Re L, Malcangi G, Martinez-Sanchez G (2012) Medical ozone is now ready for a scientific challenge: current status and future perspectives. J Exp Integr Med 2(3):193-196

255. Di Mauro R, Cantarella G, Bernardini R, Di Rosa M, Barbagallo I, Distefano A, Longhitano L, Vicario N, Nicolosi D, Lazzarino G (2019) The biochemical and pharmacological properties of ozone: the smell of protection in acute and chronic diseases. Int J Mol Sci 20(3):634

256. Bocci V, Zanardi I, Travagli V (2010) Ozonation of human HIV-infected plasmas for producing a global vaccine: how 
HIV-patients may help fight the HIV pandemia. Virulence 1(3):215-217

257. Bocci V, Travagli V, Zanardi I (2009) The failure of HIV vaccines: a new autovaccine may overcome some problems. Med Hypotheses 72(6):662-664

258. Ura T, Okuda K, Shimada M (2014) Developments in viral vector-based vaccines. Vaccines 2(3):624-641

259. Rauch S, Jasny E, Schmidt KE, Petsch B (2018) New vaccine technologies to combat outbreak situations. Front Immunol 9:1963

260. Faber M, Lamirande EW, Roberts A, Rice AB, Koprowski H, Dietzschold B, Schnell MJ (2005) A single immunization with a rhabdovirus-based vector expressing severe acute respiratory syndrome coronavirus (SARS-CoV) S protein results in the production of high levels of SARS-CoV-neutralizing antibodies. J Gen Virol 86(Pt 5):1435

261. Sutter G, Staib C (2003) Vaccinia vectors as candidate vaccines: the development of modified vaccinia virus Ankara for antigen delivery. Curr Drug Targets Infect Disord 3(3):263-271

262. Chen Z, Zhang L, Qin C, Ba L, Christopher EY, Zhang F, Wei Q, He T, Yu W, Yu J (2005) Recombinant modified vaccinia virus Ankara expressing the spike glycoprotein of severe acute respiratory syndrome coronavirus induces protective neutralizing antibodies primarily targeting the receptor binding region. J Virol 79(5):2678-2688

263. Du L, He Y, Wang Y, Zhang H, Ma S, Wong CK, Wu SH, Ng F, Huang J-D, Yuen K-Y (2006) Recombinant adeno-associated virus expressing the receptor-binding domain of severe acute respiratory syndrome coronavirus $\mathrm{S}$ protein elicits neutralizing antibodies: Implication for developing SARS vaccines. Virology 353(1):6-16

264. Kobinger GP, Figueredo JM, Rowe T, Zhi Y, Gao G, Sanmiguel JC, Bell P, Wivel NA, Zitzow LA, Flieder DB (2007) Adenovirus-based vaccine prevents pneumonia in ferrets challenged with the SARS coronavirus and stimulates robust immune responses in macaques. Vaccine 25(28):5220-5231

265. Liu R-Y, Wu L-Z, Huang B-J, Huang J-L, Zhang Y-L, Ke M-L, Wang J-M, Tan W-P, Zhang R-H, Chen H-K (2005) Adenoviral expression of a truncated S1 subunit of SARS-CoV spike protein results in specific humoral immune responses against SARS-CoV in rats. Virus Res 112(1-2):24-31

266. Shim B-S, Stadler K, Nguyen HH, Yun C-H, Kim DW, Chang J, Czerkinsky C, Song MK (2012) Sublingual immunization with recombinant adenovirus encoding SARS-CoV spike protein induces systemic and mucosal immunity without redirection of the virus to the brain. Virol J 9(1):1-9

267. Liu MA (2019) A comparison of plasmid DNA and mRNA as vaccine technologies. Vaccines 7(2):37

268. Ledwith B, Manam S, Troilo P, Barnum A, Pauley C, Griffiths T 2nd, Harper L, Schock H, Zhang H, Faris J (2000) Plasmid DNA vaccines: assay for integration into host genomic DNA. Dev Biol (Basel) 104:33-43

269. Chi H, Zheng X, Wang X, Wang C, Wang H, Gai W, Perlman S, Yang S, Zhao J, Xia X (2017) DNA vaccine encoding Middle East respiratory syndrome coronavirus $\mathrm{S} 1$ protein induces protective immune responses in mice. Vaccine 35(16):2069-2075
270. Al-Amri SS, Abbas AT, Siddiq LA, Alghamdi A, Sanki MA, Al-Muhanna MK, Alhabbab RY, Azhar EI, Li X, Hashem AM (2017) Immunogenicity of candidate MERS-CoV DNA vaccines based on the spike protein. Sci Rep 7:44875

271. Huang J, Cao Y, Du J, Bu X, Ma R, Wu C (2007) Priming with SARS CoV S DNA and boosting with SARS CoV S epitopes specific for $\mathrm{CD} 4+$ and $\mathrm{CD} 8+\mathrm{T}$ cells promote cellular immune responses. Vaccine 25(39-40):6981-6991

272. Martin JE, Louder MK, Holman LA, Gordon IJ, Enama ME, Larkin BD, Andrews CA, Vogel L, Koup RA, Roederer M (2008) A SARS DNA vaccine induces neutralizing antibody and cellular immune responses in healthy adults in a phase I clinical trial. Vaccine 26(50):6338-6343

273. Philbin VJ, Dowling DJ, Gallington LC, Cortés G, Tan Z, Suter EE, Chi KW, Shuckett A, Stoler-Barak L, Tomai M (2012) Imidazoquinoline toll-like receptor 8 agonists activate human newborn monocytes and dendritic cells through adenosine-refractory and caspase-1-dependent pathways. J Allergy Clin Immunol 130(1):195-204.e199

274. Shukla NM, Salunke DB, Balakrishna R, Mutz CA, Malladi SS, David SA (2012) Potent adjuvanticity of a pure TLR7-agonistic imidazoquinoline dendrimer. PLoS ONE 7(8):e43612

275. Ella R, Vadrevu KM, Jogdand H, Prasad S, Reddy S, Sarangi V, Ganneru B, Sapkal G, Yadav P, Abraham P (2021) Safety and immunogenicity of an inactivated SARS-CoV-2 vaccine, BBV152: a double-blind, randomised, phase 1 trial. The Lancet Infectious Diseases 21(5):637-646. https://doi.org/10.1016/ S1473-3099(20)30942-7

276. Goss AL, Samudralwar RD, Das RR, Nath A (2021) ANA investigates: neurological complications of COVID-19 vaccines. Annals of Neurology 89(5):856-857. https://doi.org/10.1002/ ana. 26065

277. Kyriakidis NC, López-Cortés A, González EV, Grimaldos AB, Prado EO (2021) SARS-CoV-2 vaccines strategies: a comprehensive review of phase 3 candidates. npj Vaccines 6(1):1-17

278. Allen A, Szabo L (2020) NIH "very concerned" about serious side effect in coronavirus vaccine trial. Scientific American, September 15

279. Voysey M, Clemens SAC, Madhi SA, Weckx LY, Folegatti PM, Aley PK, Angus B, Baillie VL, Barnabas SL, Bhorat QE (2021) Safety and efficacy of the ChAdOx $1 \mathrm{nCoV}-19$ vaccine (AZD1222) against SARS-CoV-2: an interim analysis of four randomised controlled trials in Brazil, South Africa, and the UK. Lancet 397(10269):99-111

280. Ledford H (2020) US authorization of first COVID vaccine marks new phase in safety monitoring. Nature 588(7838):377378. https://doi.org/10.1038/d41586-020-03542-4

281. Keddie S, Pakpoor J, Mousele C, Pipis M, Machado PM, Foster M, Record CJ, Keh RY, Fehmi J, Paterson RW (2021) Epidemiological and cohort study finds no association between COVID-19 and Guillain-Barré syndrome. Brain 144(2):682-693

Publisher's Note Springer Nature remains neutral with regard to jurisdictional claims in published maps and institutional affiliations. 


\section{Authors and Affiliations}

\section{Medha Karnik ${ }^{1}$ Narasimha M. Beeraka ${ }^{1,2}$. Chinnappa A. Uthaiah ${ }^{1}$ - Suma M. Nataraj ${ }^{1}$ Anjali Devi S. Bettadapura ${ }^{1}$.} Gjumrakch Aliev ${ }^{2,3,4,5} \cdot$ SubbaRao V. Madhunapantula ${ }^{1,6}$ (D)

1 Center of Excellence in Molecular Biology and Regenerative Medicine (CEMR), Department of Biochemistry, JSS

Medical College, JSS Academy of Higher Education \& Research (JSS AHER), Mysuru, Karnataka, India

2 Sechenov First Moscow State Medical University (Sechenov University), St. Trubetskaya, 8, bld. 2, Moscow 119991, Russia

3 Institute of Physiologically Active Compounds, Russian Academy of Sciences, Chernogolovka, Moscow Region 142432, Russia
4 Research Institute of Human Morphology, 3 Tsyurupy Street, Moscow 117418, Russia

5 GALLY International Research Institute, 7733 Louis Pasteur Drive, San Antonio, TX \#330, USA

6 Special Interest Group in Cancer Biology and Cancer Stem Cells (SIG-CBCSC), JSS Medical College, JSS Academy of Higher Education \& Research (JSS AHER), Mysuru, Karnataka, India 